\title{
PERDA BERBASIS SYARI'AH DALAM TINJAUAN HUKUM TATA NEGARA
}

\author{
Oleh: \\ Hayatun Na'imah \\ Fakultas Syari'ah dan Ekonomi Islam dengan konsentrasi kajian Hukum Tata Negara \\ Universitas Islam Negeri (UIN) Antasari, Banjarmasin \\ e-mail: hayatunnaimahmhum@gmail.com
}

\begin{abstract}
Local regulations are legal products that should be in accordance with and submissive to the drafting rules of Indonesian law product and legal order. Some basic consideration that can be used to review Shariah-based Regulations wheather it is acceptable or legally contradictory from the perspective of Indonesia's Constitutional Law are as follows: (1) legal order aspects, (2) regulations material aspects, (3) legal drafting aspects, (4) sanctions enactment aspects, and (5) moral ethics law aspects. In terms of the theory of the hierarchy of legal norms and formal hierarchy, these local regulations have been in accordance with Article 14 of Act 12 of 2011 on the Establishment of Legislation. In addition, from the aspects of functional hierarchy theory, the regulations have covered the procedures of their formation, that is, they have been set by the Head of Regional with the approval from DPRD (Regional People's Representative Assembly) as stipulated in Article 136 of Act 32 of 2004 on Regional Government.
\end{abstract}

\section{Keywords: Shariah-Based Local Regulations, Constitutional Law}

\begin{abstract}
Abstrak
Perda merupakan produk hukum yang harus tunduk dan patuh terhadap kaidah-kaidah pembuatan produk hukum dan tertib hukum Indonesia. Beberapa aspek untuk melihat PerdaPerda Berbasis Syari'ah dapat diterima, atau bahkan bertentangan secara yuridis dilihat dari sudut pandang Hukum Tata Negara Indonesia.(1) Dari segi tertib hokum. (2) Dari sisi materi perda. (3) Dari sisi legal drafting. (4) Dari sisi penerapan sanksi. (5) Dari aspek etika moral hokum. Dari aspek teori hirarki norma hokum dan dari segi hirarki formal bahwa Perda-perda tersebut di atas telah sesuai dengan Pasal 14 Undang-undang No. 12 Tahun 2011 tentang Pembentukan Peraturan Perundang-undangan dan dari teori hirarki fungsional perda terebut telah menempuh prosuder pembentukannya, yaitu telah ditetapkan oleh Kepala Daerah
\end{abstract}


setelah mendapat persetujuan bersama DPRD sebagaimana yang diatur dalam Pasal 136 Undang-undang No.32 Tahun 2004 tentang Pemerintahan Daerah.

\section{Kata Kunci; Perda berbasis syari’ah, Hukum Tata Negara.}

\section{Pendahuluan.}

Kewenangan yang diberikan oleh Pemerintah Pusat kepada Pemerintah Daerah biasanya sangat terbatas. Seringkali disebut karakter negara kesatuan itu sentralistis. Hal ini berbeda dengan negara yang berbentuk federal. Dalam negara federal, negara-negara bagian relatif lebih memiliki ruang gerak kekuasaan negara terdesentralisasikan kenegara bagian. Karakter yang melekat pada negara federal adalah desentralistik dan lebih demokratis.

Menurut Fred Isjwara, ${ }^{1}$ negara kesatuan adalah bentuk kenegaraan yang paling kokoh, jika dibandingkan dengan federal dan nonfederal. Dalam negara kesatuan terdapat, baik persatuan (union) maupun kesatuan (unity). Dilihat dari segi susunan negara kesatuan, maka negara kesatuan bukan negara tersusun dari beberapa negara melainkan negara tunggal.

Abu Daud Busroh mengutarakan, negara kesatuan adalah negara yang tidak tersusun daripada beberapa negara, seperti halnya dalam negara federasi, melainkan negara itu sifatnya tunggal, artinya hanya ada satu negara tidak ada negara dalam negara. Jadi dengan demikian dalam negara kesatuan itu juga hanya ada satu pemerintahan, yaitu Pemerintah Pusat yang mempunyai wewenang tertinggi dalam segala lapangan pemerintahan. Pemerintah Pusat inilah yang pada tingkat terakhir dan tertinggi dapat memutuskan segala sesuatu dalam negara tersebut. ${ }^{2}$

Negara kesatuan dapat dibedakan dalam dua bentuk, pertama; negara kesatuan dengan sistem sentralisasi. Kedua; negara kesatuan dengan sistem desentralisasi. Dalam negara kesatuan dengan sistem sentralisasi segala sesuatu di dalam negeri diatur dan diurus oleh Pemerintah Pusat dan daerah-daerah hanya tinggal melaksanakan segala sesuatu yang telah diinstruksikan oleh Pemerintah Pusat. Sedangkan dalam negara kesatuan dengan sistem desentralisasi, kepada daerah diberikan kesempatan dan kekuasaan untuk mengatur dan mengurus rumah tangganya sendiri (Otonomi Daerah) yang dinamakan daerah otonom. ${ }^{3}$

1 Fred Isjwara, Pengantar Ilmu Politik, Cetakan Kelima, (Bandung; Bina Cipta, 1974), hlm 188.

2 Abu Daud Busroh, Ilmu Negara, Cetakan Pertama, (Jakarta; Bumi Aksara, 1990) hlm 64-65.

3 Fahmi Amruzy, Otonomi Daerah dalam Negara Kesatuan, dalam Abdurrahman (editor), Beberapa Pemikiran Tentang Otonomi Daerah, (Jakarta; Media Sarana Press, 1987) hlm 56. 
Pembentukan organisasi-organisasi pemerintahan di daerah atau Pemerintah Daerah tidak sama dengan pembentukan negara bagian seperti dalam negara federal. Kedudukan Pemerintah Daerah dalam sistem negara kesatuan adalah sub divisi pemerintahan nasional. Pemerintah Daerah tidak memiliki kedaulatan sendiri sebagaimana negara bagian dalam sistem federal. Hubungan Pemerintah Pusat dengan Pemerintah Daerah adalah depent and sub ordinat, sedangkan hubungan negara bagian dengan negara federal/pusat dalam negara federal adalah indepent dan koordinat. Berdasarkan konsepsi demikian, pada dasarnya kewenangan pemerintah baik politik maupun administrasi dimiliki secara tunggal oleh Pemerintah Pusat. Pemerintah pada hakekatnya tidak mempunyai kewenangan pemerintahan. Pemerintah Daerah baru mempunyai kewenangan pemerintahan setelah memperoleh penyerahan dari Pemerintah Pusat. (desentralis/devolusi) ${ }^{4}$

\section{Konsep Negara Hukum.}

Ide negara hukum pertama kali diperkenalkan dalam ketatanegaraan Hindia Belanda melalui Regeringlement (RR) tahun 1954. Oleh karena itu ide negara hukum Republik Indonesia hendaklah disadari bahwa ide rechstaat mempunyai pengaruh cukup besar dan disisi lain kecendrungan nasional untuk merumuskan suatu konsep negara hukum khas Indonesia. Ide khas tersebut sering kita dengar seperti, negara hukum Pancasila atau negara hukum berdasarkan Pancasila. ${ }^{5}$ Dengan demikian, ide dasar negara hukum Indonesia tidaklah lepas dari ide dasar rechstaat.

Syarat-syarat dasar rechstaat seperti disebutkan pada halaman sebelumnya, bahwa syarat-syarat dasar tersebut seharusnya juga menjadi syarat dasar negara hukum Pancasila. Hal tersebut kiranya dibutuhkan suatu usaha besar berupa suatu kajian yang sangat mendasar terutama tentang ide bernegara bangsa Indonesia. Di samping itu tentunya kita tidak menutup mata terhadap perkembangan konsep negara hukum yang telah terjadi diberbagai negara seperti konsep rechsatat yang telah berkembang dari konsep "liberal-democratische rechstaat" ke "sociale rechstaat" yang pada saat ini sudah dirasakan bahwa konsep terakhir itu sudah tidak memadai. ${ }^{6}$ Untuk menentukan apakah suatu negara dapat dikategorikan

4 Bheunyamin Hoessein, dalam Hanif Nurcholis, Teori dan Praktek Pemerintahan dan Otonomi Daerah, Cetakan Pertama, (Jakarta; Grasindo, 2005) hlm 6.

5 Pilipus M Hadjon, Ide Negara Hukum Dalam Sistem Ketatanegaraan Republik Indonesia. dalam Bagir Manan (editor), Kedaulatan Rakyat Hak Asasi Manusia dan Negara Hukum, (Jakarta; Gaya Media Pratama,1996) hlm 77.

6 Ibid., hlm 5. 
sebagai negara hukum, biasanya digunakan dua macam asas, yakni, asas legalitas dan asas perlindungan atas kebebasan setiap orang dan atas hak-hak asasi manusia. ${ }^{7}$

Asas legalitas merupakan unsur utama daripada suatu negara hukum. Semua tindakan negara harus berdasarkan dan bersumber pada undang-undang. Penguasa tidak boleh keluar dari rel-rel dan batas-batas yang telah ditetapkan dalam undang-undang. Batas kekuasaan negara ditetapkan dalam undang-undang, tetapi untuk dinamakan negara hukum tidak cukup bahwa suatu negara hanya semata-mata bertindak dalam garis-garis kekuasaan yang diberikan kepadanya oleh undang-undang. ${ }^{8}$ Sudah barang tentu bahwa dalam negara hukum setiap orang yang merasa hak-hak pribadinya dilanggar, diberi kesempatan seluas-luasnya untuk mencari keadilan dengan mengajukan perkaranya tersebut di hadapan pengadilan. Cara-cara mencari keadilan itu pun dalam negara hukum diatur dengan undang-undang. ${ }^{9}$

Asas perlindungan dalam negara hukum nampak antara lain dalam "Declaration of Independence", bahwa orang yang hidup di dunia ini sebenarnya telah diciptakan merdeka oleh Tuhan, dengan dikaruniai beberapa hak yang tidak dapat dirampas atau dimusnahkan. Hak-hak tersebut yang sudah ada sejak orang dilahirkan, perlu mendapat perlindungan secara tegas dalam negara hukum modern. Menurut Sahardjo, ${ }^{10}$ peradilan tidak semata-mata melindungi hak asasi perseorangan, melainkan fungsi hukum adalah untuk mengayomi masyarakat sebagai totalitas, agar supaya cita-cita luhur bangsa tercapai dan terpelihara. Peradilan mempunyai maksud membina, tidak semata-mata menyelesaikan perkara. Hakim harus mengadili menurut hukum dan menjalankan dengan kesadaran akan kedudukan, fungsi, dan sifat hukum. Kesadaran bahwa tugas hakim ialah dengan bertanggungjawab kepada diri sendiri dan kepada nusa dan bangsa turut serta membangun dan menegakkan masyarakat adil dan makmur yang berkepribadian Pancasila.

Muh. Yamin mengatakan, ${ }^{11}$ bahwa untuk menentukan apakah suatu negara merupakan negara hukum, semata-mata didasarkan pada asas legalitas. Di sisi lain, Gouw Giok Siong ${ }^{12}$ menyatakan bahwa asas legalitas, hanyalah merupakan satu unsur atau salah satu corak dari negara hukum, karena di samping unsur asas legalitas tersebut masih perlu juga diperhatikan

7 Utrecht, Pengantar Hukum Administrasi Negara Indonesia, (Jakarta; Ichtiar, 1963), hlm 310.

8 Gouw Giok Siong, Pengertian tentang Negara Hukum, (Jakarta; Keng Po, 1955), hlm 12-13.

9 Rochmat Soemitro, Peradilan Administrasi dalam Hukum Pajak di Indonesia, Cetakan Keenam, (JakartaBandung; Eresco,1976) hlm 18.

10 Ibid, hlm 20-21

11 Yamin, Muh., Proklamasi dan Konstituante Republik Indonesia, Cetakan Kedua, (Jakarta; Djambatan,1952) hlm 9.

12 Ibid., hlm 23. 
unsur-unsur lainnya antara lain kesadaran hukum, perasaan keadilan dan perikemanusiaan, baik bagi rakyat maupun pimpinannya.

Mengenai asas perlindungan, dalam Undang-umdang Dasar 1945 ada ketentuan yang menjamin hak-hak asasi manusia. Ketentuan tersebut antara lain :

a. Kemerdekaan berserikat dan berkumpul (Pasal 28);

b. Kemerdekaan mengeluarkan pikiran dengan lisan dan tulisan (Pasal 28);

c. Hak bekerja dan hidup (Pasal 27 ayat (2));

d. Kemerdekaan agama (Pasal 29 ayat (2));

e. Hak untuk ikut mempertahankan negara (Pasal 30);

Rochmat Soemitro ${ }^{13}$ menyatakan bahwa dengan adanya Majelis Pertimbangan Pajak, seseorang dapat mengajukan surat bandingnya untuk hal-hal dimana ia merasa telah diperlakukan tidak sebagaimana mestinya oleh pejabat perpajakan. Orang dapat menuntun/mengajukan gugatan kepada negara bila oleh negara dilakukan suatu perbuatan yang melawan hukum (onrechtmatigedaad), bahwa seseorang dapat melakukan gugatan terhadap Pemerintah Republik Indonesia jika putusan pejabat yang berwenang dirasa tidak adil. Lebih lanjut ia menjelaskan bahwa sudah banyak peraturan-peraturan yang memberi jaminan kepada para warga negara, untuk menggunakan hak-haknya mengajukan tuntutantuntutan di muka pengadilan, bila hak-hak dasarnya atau kebebasannya dilanggar.

Pengakuan dan perlindungan terhadap hak-hak asasi manusia, mendapat tempat utama dan dapat dikatakan sebagai tujuan dari pada negara hokum, sebaliknya dalam negara totaliter tidak ada tempat bagi hak-hak asasi manusia. Istilah "rechtstaat" mulai populer sejak abad XIX, meskipun pemikiran tentang itu sudah lama adanya. Istilah "the rule of law" mulai popular dengan terbitnya buku dari Albert Ven Dicey tahun 1885 dengan judul "Introduction to the study of the constitution".

Dari latar belakang dan sistem hukum yang menopangnya terdapat perbedaan antara konsep "rechtstaat" dengan konsep "the rule of law", pada dasarnya kedua konsep itu mengarahkan dirinya pada satu sasaran yang utama yaitu pengakuan dan perlindungan terhadap hak-hak asasi manusia. Meskipun dengan sasaran yang sama, tetapi keduanya tetap berjalan dengan sistemnya sendiri yaitu sistem hukum sendiri. Konsep "rechtstaat" lahir dari suatu perjuangan menentang absolutisme sehingga sifatnya revolusioner, sebaliknya konsep "the rule of law" berkembang secara evolusioner. Hal ini nampak dari isi atau kriteria "rechtstaat" dan kriteria "the rule of law". Konsep "rechtstaat" bertumpu atas sistem hukum

13 Rohmat Soemitro, Op.Cit, hlm 25. 
continental yang disebut "civil law" atau "modern roman law", sedangkan konsep "the rule of law" bertumpu atas sistem hukum yang disebut "common law". Karakteristik "civil law" adalah "administrative", sedangkan karakteristik "common law" adalah "judicial". Perbedaan karakter yang demikian disebabkan karena latar belakang daripada kekuasaan raja. ${ }^{14}$

Pada zaman Romawi, kekuasaan yang menonjol dari raja yakni membuat peraturan melalui dekrit. Kekuasaan itu kemudian didelegasikan kepada pejabat-pejabat administratif, sehingga pejabat-pejabat administratif yang membuat pengarahan tertulis bagi hakim tentang bagaimana menyelesaikan suatu sengketa. Begitu besar peran administrasi negara sehingga tidaklah mengherankan, kalau dalam sistem continental-lah pertama muncul cabang hukum baru yang disebut "droit administrative", dan intinya adalah hubungan antara administrasi negara dengan rakyat. Sebaliknya di Inggris, kekuasaan utama dari raja adalah memutus perkara. Peradilan oleh raja kemudian berkembang menjadi suatu peradilan, sehingga hakim-hakim peradilan adalah delegasi dari raja, tetapi bukan melaksanakan kehendak raja. Hakim harus memutus perkara berdasarkan kebiasaan umum Inggris (the common custom of England), sebagaimana dilakukan oleh raja sendiri sebelumnya. Dengan demikian nampak bahwa di Eropa peranan administrasi negara bertambah besar, sedangkan di Inggris peranan peradilan dan para hakim bertambah besar.

Sehubungan dengan latar belakang tersebut, di Eropa dipikirkan langkah-langkah untuk membatasi kekuasaan administrasi negara, sedangkan di lnggris dipikirkan langkah-langkah untuk mewujudkan suatu peradilan yang adil. Dalam perjalanan waktu, konsep "rechtstaat" telah mengalami perkembangan dari konsep klasik ke konsep modern. Sesuai dengan sifat dasarnya konsep klasik disebut "klasiek liberale en democratische rechtstaat", yang sering disingkat dengan "democratische rechtsstaat". Konsep modern lazimnya disebut "sociale rechtstaat" atau "sociale democratische rechtstaat". ${ }^{15}$ Sifatnya yang liberal bertumpu atas pemikiran kenegaraan dari John Locke, Montesquieu dan Immanuel Kant. Sifatnya yang demokratis bertumpu atas pemikiran kenegaraan dari J.J. Rousseau tentang kontrak sosial. ${ }^{16}$

14 Philipus M Hadjon,., Perlindungan Hukum Bagi Rakyat di Indonesia, Sebuah Studi tentang Pinsipprinsipnya, Penanganannya oleh Pengadilan Dalam Lingkungan Peradilan Umum dan Pembentulan Peradilan Administrasi Negara, (Surabaya; Bina Ilmu, 1987) hlm 71

15 Ibid, hlm 74.

16 Couwenberg S.W-, Westers Staotsrecht als Emancipatie Proces, Samson, Alphen aan de Rijn, 1977, hlm. 25. Dikutip dari, Agus Budi Setiyono, Pembentukan Peraturan Hukum Daerah Yang Demokratis Oleh Pemerintah Daerah, tesis, Program Magister Ilmu Hukum PPS Universitas Diponegoro, Semarang, 2008, hlm 36. 
Prinsip liberal bertumpu atas "liberty" (vrijheid) dan prinsip demokrasi bertumpu atas "equality" (gelijkheid). "Liberty" menurut Immanuel Kant adalah "the free self-assertion of each-limited only by the like liberty of all". Atas dasar itu "liberty" merupakan suatu kondisi yang memungkinkan pelaksanaan kehendak secara bebas dan hanya dibatasi seperlunya untuk menjamin koeksistensi yang harmonis antara kehendak bebas individu dengan kehendak bebas semua yang lain. Dari sinilah mangalir prinsip selanjutnya yaitu: "freedom from arbitrary and unreasonable exercise of the power and authority'. ${ }^{17}$ Konsep "equality" mengandung makna yang abstrak dan formal (abstract-formal equality) dan dari sini mengalir prinsip "one man-one vote". 18

Menurut S.W. Couwenberg, prinsip-prinsip dasar yang sifatnya liberal dari "rechtstaat" meliputi; ${ }^{19}$

1) pemisahan antara negara dengan gereja;

2) adanya jaminan atas hak-hak kebebasan sipil (burgelijke vrijheidsrechten);

3) persamaan terhadap undang-undang (geliikheid vor de wet);

4) adanya konstitusi tertulis sebagai dasar kekuasaan negara dan dasar sistem hukum;

5) pemisahan kekuasaan berdasarkan trias politica dan sistem "check and balances";

6) asas legalitas (heerschappij van de wet);

7) ide tentang aparat pemerintah dan kekuasaan kehakiman ymg tidak memihak dan netral;

8) prinsip perlindungan hukum bagi rakyat terhadap penguasa oleh pengadilan yang bebas dan tidak memihak dan berbarengan dengan prinsip-prinsip tersebut, diletakkan prinsip tanggung gugat negara secara yuridis;

9) prinsip pembagian kekuasaan, baik territorial sifatnya maupun vertikal (federasi maupun desentralisasi);

C.W. Van der Port menjelaskan ${ }^{20}$ bahwa atas dasar demokratis, "rechtstaat" dikatakan sebagai "negara kepercayaan timbal balik" (de staat van het wederziids vertrowen) yaitu kepercayaan dari pendukungnya bahwa kekuasaan yang diberikan tidak akan disalahgunakan, dia mengharapkan kepatuhan dari rakyat pendukungnya.

17 Roscoe Pound, The Development of Constitutional Guaranties of Liberty, Yale University Press, New Haven London, 1957, hlm. 1-2, dikutip dari, Ibid, hlm 37.

${ }^{18}$ Ibid., hlm 38

19 Ibid.

20 Port, C.W. van der, - bewerk door A.M. Donner, Handboek van het nederlanse Staatsrecht, II e druk ljeenk Willink, Zwolle, 1983, hlm 143, dikutip dari, Ibid, hlm 38. 
S.W. Couwenberg menjelaskan bahwa asas-asas demokratis yang melandasi "rechtstaat" meliputi 5 asas yakni $:^{21}$

a. asas hak-hak politik (het beginsel van de politieke grondrechten);

b. asas mayoritas;

c. asas perwakilan;

d. asas pertanggungiawaban;

e. asas publik (openbaarheids beginsel);

Dengan demikian maka atas dasar sifat-sifat tersebut, yakni sifat liberal dan demokratis, ciri-ciri "rechtstaat" adalah $:^{22}$

1) Adanya Undang-undang Dasar atau Konstitusi yang memuat ketentuan tertulis tentang hubungan antara penguasa dan rakyat;

2) Adanya pembagian kekuasaan negara yang meliputi, kekuasaan pembuatan Undang-undang yang berada pada parlemen, kekuasaan kehakiman bebas dan tidak hanya menangani sengketa antara individu rakyak tetapi juga antara rakyat dan penguasa dan pemerintah mendasarkan tindakannya atas Undang-undang (wetmatig bestuur);

3) Diakui dan dilindunginya hak-hak rakyat yang sering disebut "vrijheidsrechten van burger;

Philipus M. Hadjon menjelaskan, dalam kaitannya dengan ciri-ciri di atas menunjukkan dengan jelas bahwa ide sentra "rechtstaat" adalah pengakuan dan perlindungan terhadap hak-hak asasi manusia yang bertumpu atas prinsip kebebasan dan persamaan. Adanya Undang-undang Dasar akan memberikan jaminan konstitusional terhadap asas kebebasan dan persamaan. Adanya pembagian kekuasaan untuk menghindarkan penumpukan kekuasaan dalam satu tangan, yang sangat cenderung kepada penyalahgunaan kekuasaan, berarti pemaksaan terhadap kebebasan dan persamaan. Adanya pembuatan undang-undang yang dikaitkan dengan parlemen, dimaksudkan untuk menjamin bahwa hukum yang dibuat adalah atas kehendak rakyat, dengan demikian hukum tersebut tidak akan mengabaikan hakhak rakyat tetapi dikaitkan dengan asas mayoritas, kehendak rakyat diartikan sebagai kehendak golongan mayoritas. Prinsip "wetmatig bestuur" agar tindak pemerintahan tidak memaksa kebebasan dan persamaan (heerschoppij van de wet). Dalam konsep "rechtstaat" yang liberal dan demokratis, inti perlindungan hukum bagi rakyat adalah perlindungan

21 Ibid, hlm 30.

22 Ibid, hlm 143. 
terhadap kebebasan individu. Setiap tindak pemerintahan yang melanggar kebebasan individu melahirkan hak untuk menggugat di muka peradilan. ${ }^{23}$

Menurut D.H.M. Meuwissen, dikaitkan dengan perlindungan hukum bagi rakyat terhadap tindak pemerintahan, dalam "sociale rechtstaat" prinsip perlindungan hukum terutama diarahkan kepada perlindungan terhadap hak-hak sosial, hak-hak ekonomi, dan hakhak kultural. Dikaitkan dengan sifat hak, dalam "rechtstaat" yang liberal dan demokratis adalah "the right to do", dalam "sociale rechtstaat" muncul "the right to receive". Dikaitkan dengan sarana perlindungan hukum, maka makin kompleks sistem perlindungan hukum bagi rakyat. $^{24}$

Konsep yuridis "sociale rechtstaat", P. Schnabel menjelaskan bahwa tugas negara disamping melindungi kebebasan sipil juga melindungi gaya hidup rakyat. ${ }^{25}$ P. Schnabel menjelaskan, ${ }^{26}$ bahwa pengaruh negara terhadap individu menjelma dalam tiga cara yakni: Pertama, pengaruh langsung sebagai akibat dari pengakuan dan perlindungan terhadap hakhak social. Kedua, pengaruh tidak langsung sebagai akibat dari pembentukan aparat pemerintah yang dilengkapi dengan kekuasaan jabatan dan keahlian. Ketiga, harapan bahwa problema-problema masyarakat dapat dipecahkan melalui campur tangan penguasa.

Konsep "the rule of law" maupun konsep "rechtstaat" menempatkan pengakuan dan perlindungan terhadap hak-hak asasi manusia sebagai titik sentralnya, sedangkan bagi Negara Republik Indonesia, yang menjadi titik sentralnya adalah "keserasian hubungan antara pemerintah dan rakyat berdasarkan asas kerukunan”. Untuk melindungi hak-hak asasi manusia dalam konsep "the rule of law" mengedepankan prinsip "equality before the law", dan dalam konsep "rechtstaat" mengedepankan prinsip "wetmatigheid" kemudian menjadi "rechtmatigheid". Negara Republik Indonesia yang menghendaki keserasian hubungan antara pemerintah dan rakyat yang mengedepankan adalah "asas kerukunan" dalam hubungan antara pemerintah dan rakyat. Dari asas ini akan berkembang elemen lain dari konsep Negara Hukum Pancasila, yakni terjalinnya hubungan fungsional antara kekuasaan-kekuasaan negara, penyelesaian sengketa secara musyawarah, sedangkan peradilan merupakan sarana terakhir dan tentang hak-hak asasi manusia tidaklah hanya menekankan hak dan kewajiban saja, tetapi juga terjalinnya suatu keseimbangan antara hak dan kewajiban.

\footnotetext{
23 Ibid., hlm 76-77.

24 Meuwissen, D.H.M., Elementen van Staatsrecht, Tjeenk Willink, Zwolle, 1975, hlm 140.

25 Idenberg, Ph. A., red., De Nadagen van de Verzorgingstaat Kansen en Prespectiven var Morgen. Meulenhoff Informatief, Amsterdam 1983, hlm 27, dikutip dari, Ibid, hlm 40.

26 Ibid., hlm 41-42.
} 


\section{Eksistensi Peraturan Hukum Daerah yang Bersifat Demokratis Partisipatif}

Eksistensi peraturan hukum daerah yang bersifat demokratis partisipatif dilihat dari pelaksanaan asas keterbukaan dalam pembentukan peraturan hukum daerah. Pada pembahasan awal mengenai prosedur dan mekanisme pembentukan peraturan hukum daerah telah diuraikan bahwa prosedur dan mekanisme pembentukan peraturan hukum daerah berdasarkan jenis peraturan hukum daerah terdapat perbedaan. Prosedur dan mekanisme pembentukan Peraturan Daerah berbeda dengan prosedur dan mekanisme pembentukan Keputusan Kepala Daerah.

Prosedur pembentukan Peraturan Daerah dilalui dengan beberapa tahapan, yaitu tahapan penyusunan rancangan, tahapan pembahasan, tahapan akhir, dan penetapan Rancangan Peraturan Daerah ( Raperda) menjadi Peraturan Daerah (Perda). Rancangan Peraturan Daerah dapat berasal dari Kepala Daerah dan dapat berasal prakarsa DPRD. ${ }^{27}$

Rancangan Peraturan Daerah yang berasal dari Kepala Daerah, pokok-pokok materi rancangan Peraturan Daerah disiapkan oleh unit kerja. Selanjutnya disampaikan kepada bagian hukum untuk memperoleh tanggapan yuridis baik mengenai materi, susunan atau bentuk dan bahasanya. Kemudian disampaikan kembali kepada instansi atau unit kerja yang mengajukannya untuk disempurnakan. Setelah itu disampaikan kepada Kepala Daerah untuk mendapat persetujuan. ${ }^{28}$

Rancangan Peraturan Daerah yang telah mendapat persetujuan Kepala Daerah kemudian disampaikan kepada DPRD dengan surat sekretaris daerah. Kemudian rancangan Peraturan Daerah tersebut diadakan pra pembahasan. Dalam pra pembahasan diikuti oleh unit kerja yang mengerjakan Raperda dan unit kerja yang terkait, DPRD yang biasanya diwakili oleh Tim atau Pansus, tokoh-tokoh masyarakat dan Lembaga Swadaya Masyarakat (LSM). ${ }^{29}$

Rancangan Peraturan Daerah yang berasal dari usul prakarsa DPRD. Usul prakarsa tersebut disampaikan kepada pimpinan DPRD dalam bentuk rancangan Peraturan Daerah disertai penjelasan secara tertulis. Kemudian rancangan Peraturan Daerah usul prakarsa DPRD tersebut diberikan nomor pokok oleh sekretariat DPRD. Rancangan Peraturan Daerah usul prakarsa tersebut oleh pimpinan DPRD disampaikan dalam rapat pimpinan DPRD, para pengusul diberi kesempatan untuk memberi penjelasan atas rancangan Peraturan Daerah usul prakarsa DPRD. Pembicaraan mengenai sesuatu untuk prakarsa dilakukan dengan memberikan pandangan dari Kepala Daerah untuk memberikan pendapat dan para pengusul

27 Kasubbag Perundang-undangan Bagian Hukum Sekertaris Daerah Provinsi Kalimantan Selatan.

28 Ibid.

29 Ibid. 
untuk memberikan jawaban atas pandangan anggota DPRD lainnya dari pendapat Kepala Daerah. Pembicaraan diakhiri dengan ketentuan DPRD yang menerima atau menolak usul prakarsa menjadi prakarsa DPRD. ${ }^{30}$

Rancangan Peraturan Daerah baik yang berasar dari Kepala Daerah maupun yang berasal dari inisiatif DPRD dilakukan pembahasan. Pembahasan rancangan Peraturan Daerah dilakukan dengan komisi-komisi yaitu komisi A yang membidangi pemerintahan, kependudukan, pertahanan sipil, pertahanan ketertiban masyarakat (humas, penerangan/pers, hukum/perundang-undangan, kepegawaian, sosial dan politik, organisasi, dan Bappeda. ${ }^{31}$

Tata cara penyampaian rancangan Peraturan Daerah sebagai berikut: Rancangan Peraturan Daerah yang berasal dari Kepala Daerah disampaikan kepada pimpinan DPRD dengan surat Kepala Daerah. Rancangan Peraturan Daerah yang berasal dari usul prakarsa DPRD beserta penjelasannya disampaikan secara tertulis kepada Kepala Daerah. Rancangan Peraturan Daerah yang berasal dari Kepala Daerah dan usul prakarsa DPRD tersebut disampaikan oleh pimpinan DPRD kepada seluruh Anggota DPRD selambat-lambatnya 7 (tujuh) hari sebelum Rapat diselenggarakan. ${ }^{32}$

Apabila ada 2 (dua) rancangan Peraturan Daerah yang diajukan mengenai hal yang sama dan waktu yang bersamaan, maka yang dibicarakan adalah rancangan Peraturan Daerah yang diterima terlebih dahulu dan rancangan Peraturan Daerah yang diterima kemudian dipergunakan sebagai pelengkap pembahasan ancangan Peraturan Daerah dilakukan melalui 4 (empat) tahapan yaitu Tahap I, II, III, IV kecuali apabila panitia musyawarah menentukan lain. Sebelum dilakukan pembicaraan Tahap II dilakukan dalam rapat komisi/rapat gabungan komisi atau dalam rapat panitia khusus.

Pembicaraan Tahap I meliputi: Penjelasan Kepala Daerah dalam rapat paripurna terhadap rancangan Peraturan Daerah yang berasal dari Kepala Daerah; penjelasan dalam rapat paripurna oleh pimpinan komisi/rapat gabungan komisi atau pimpinan panitia khusus atas nama DPRD terhadap usul rancangan Peraturan Daerah.

Pembicaraan Tahap II meliputi; Pertama, dalam hal penyampaian rancangan Peraturan Daerah yang berasal dari Kepala Daerah diawali dengan pandangan umum dalam rapat paripurna oleh fraksi-fraksi terhadap rancangan Peraturan Daerah, kemudian jawaban Kepala Daerah dalam rapat paripurna terhadap pandangan umum fraksi-fraksi. Kedua, dalam hal penyampaian rancangan Peraturan Daerah prakarsa DPRD diawali dengan penyampaian

\footnotetext{
30 Tata Tertib DPRD Provinsi Kalimantan Selatan

31 Ibid...

32 Ibid...
} 
pendapat Kepala Daerah dalam rapat paripurna terhadap rancangan Peraturan Daerah unsur prakarsa DPRD, kemudian jawaban pimpinan komisi/kapat gabungan komisi atau pimpinan panitia khusus atas nama DPRD dalam Rapat paripurna terhadap pendapat Kepala Daerah.

Pembicaraan Tahap III meliputi; pembahasan dalam rapat komisi/rapat gabungan komisi atau rapat panitia khusus yang dilakukan bersama-sama dengan pejabat daerah yang ditunjuk oleh Kepala Daerah.

Pembicaraan Tahap IV meliputi; Pertama, pengambilan keputusan dalam rapat paripurna yang didahului dengan laporan hasil pembicaraan tahap III dan pendapat akhir fraksi-fraksi. Kedua, pemberian kesempatan kepada Kepala Daerah untuk menyampaikan sambutan terhadap pengambilan keputusan Peraturan Daerah yang telah memperoleh persetujuan DPRD ditandatangani oleh Kepala Daerah. Persetujuan DPRD ditetapkan dengan Surat Keputusan DPRD. Kepala Daerah dengan persetujuan DPRD menetapkan Peraturan Daerah. Rancangan Peraturan Daerah dapat berasal dari Kepala Daerah atau atas usul prakarsa dan DPRD. Peraturan Daerah ditandatangani oleh Kepala Daerah. Persetujuan DPRD ditetapkan dalam surat keputusan DPRD. Rapat-rapat dalam membahas rancangan Peraturan Daerah mengenai Anggaran Pendapatan dan Belanja Daerah dilakukan dalam rapat yang khusus yang diadakan untuk keperluan itu.

Prosedur pembentukan Keputusan Kepala Daerah baik yang sifatnya mengatur maupun yang sifatnya penetapan (beschikking) materi seluruhnya disiapkan oleh Kepala Daerah, yaitu unit-unit kerja yang memerlukan pengaturan hal tertentu melalui Keputusan Kepala Daerah. Rancangan Keputusan Kepala Daerah tidak memerlukan pra-pembahasan seperti pada Rancangan Peraturan Daerah. Terhadap suatu Rancangan Keputusan Kepala Daerah dapat dilakukan pembahasan dalam komisi-komisi yang membidangi bidang hukum dan perundang-undangan yaitu Komisi A. Namun dalam kenyataan sangat jarang dilakukan pembahasan terhadap Rancangan Keputusan Kepala Daerah di DPRD, cukup dengan meminta pertimbangan.

Berdasarkan uraian-uraian tersebut secara normatif asas keterbukaan diatur dalam peraturan tata tertib DPRD yang menyatakan bahwa setiap rapat persidangan bersifat terbuka untuk umum. Akan tetapi secara empirik pelaksanaan asas keterbukaan masih sangat terbatas sehingga eksistensi peraturan hukum daerah yang demokratis partisipatif sangat sulit untuk diwujudkan. Hal ini terbukti dari prosedur pembentukan peraturan hukum daerah baik dalam prosedur maupun registrasi. Dalam prosedur pembentukan peraturan hukum daerah partisipasi masyarakat sangat kecil karena rakyat tidak pernah diberitahukan tentang pembentukan suatu peraturan hukum daerah. Kemudian masyarakat juga tidak pernah 
dilibatkan untuk turut berfikir tentang materi-materi yang akan diatur. Kalaupun ada hanya sebatas menyampaikan aspirasi yang belum tentu diwujudkan dalam materi pengaturan karena keputusan akhir dari seluruh proses ada pada Kepala Daerah. Keterbukaan prosedur dalam musyawarah nampak ada upaya melibatkan masyarakat dalam pra-pembahasan dan pembahasan. Kalaupun ada sangat terbatas karena hanya perwakilan yang belum tentu representasi dari seluruh rakyat dan golongan. Dan keterlibatan perwakilan rakyat juga tidak aktif dalam sidang pembahasan karena terlalu protokoler. Hal ini sangat sulit diwujudkan dalam pelaksanaan. Wewenang untuk memutus dan menetapkan ada pada eksekutif dan legislatif. Keterbukaan dalam registrasi dilakukan dengan menempatkan Peraturan Daerah dan Keputusan Kepala Daerah dalam Lembaran Daerah. Wewenang pengundangan ada pada sekretaris daerah.

Padahal idealnya keterbukaan dalam prosedur pembentukan peraturan hukum daerah memungkinkan masyarakat mengetahui prosedur pembentukannya sendiri dan mengetahui materi-materi yang diatur serta mengetahui adanya peraturan hukum daerah mengenai hal tertentu. Keterbukaan dalam prosedur pembentukan peraturan hukum daerah memungkinkan masyarakat ikut memikirkan materi-materi muatan yang harus diatur dalam suatu peraturan hukum dengan menyampaikan aspirasinya secara langsung. Keterbukaan dalam prosedur pembentukan peraturan hukum daerah memungkinkan masyarakat ikut bermusyawarah pada setiap tahapan persidangan rapat pembahasan atas suatu rancangan Peraturan Daerah baik pada tingkat pra-pembahasan (eksekutif) maupun pembahasan di lembaga legislatif (DPRD). Keterbukaan dalam prosedur pembentukan peraturan hukum daerah memungkinkan masyarakat ikut memutuskan dalam rangka pelaksanaan. Dengan adanya ruang untuk ikut memutuskan, maka rakyat akan merasa terikat baik secara moral maupun secara hukum ada keharusan atau kewajiban untuk ikut bertanggung jawab dalam pelaksanaan suatu peraturan hukum daerah.

Berdasarkan berbagai uraian tersebut dapat diketahui bahwa : ${ }^{33}$

1) Pengaturan peran serta masyarakat dalam pembentukan peraturan hukum daerah masih sangat sumir yakni dalam tata tertib DPRD, tetapi masyarakat tidak diberikan kesempatan berpartisipasi secara langsung, melainkan terbatas hanya sebagai penonton saja;

33 Satjipto Rahardjo, Penyusunan Undang-undang yang Demokratis, makalah dalam seminar, Mencari Model Ideal Penyusunan Undang-undang yang Demokratis dan Kongres Asosiasi Sosiologi Hukum Indonesia, FH Undip, Semarang, 1998, dikutip dari, Saifudin, Partisipasi Publik dalam Pembentukan Peraturan Perundang-undangan, (Yogyakarta; FH UII Press, 2009) hlm 1. 
2) Peran serta masyarakat lebih bermakna sebagai pemberdayaan masyarakat untuk ikut membicarakan, mengkritisi, menanggapi, dan turut memberikan dukungan dan atau penolakan atas sesuatu kebijakan daerah yang dikemas dalam suatu peraturan hukum daerah;

Selain hal tersebut pembentukan peraturan hukum adalah bagian dari aktivitas dalam mengatur masyarakat yang terdiri atas gabungan individu-individu manusia dengan segala dimensinya.

\section{Konsep Desentralisasi dan Otonomi.}

Desentralisasi pada dasarnya terjadi setelah sentralisasi melalui asas dekonsentrasi tidak dapat melaksanakan tugas pemerintahan secara baik dalam arti pemerintahan gagal dalam mewujudkan pemerintahan yang demokratis. Suatu pemerintahan yang mampu mengakomodasikan unsur-unsur yang bersifat kedaerahan berdasarkan aspirasi masyarakat daerah. Oleh karena itu, urusan pemerintahan yang merupakan wewenang pemerintah (pusat) sebagian harus diserahkan kepeda organ negara yang lain di daerah (Pemerintah Daerah), untuk diurus sebagai rumah tangganya. Proses penyerahan sebagian urusan pemerintahan kepada daerah untuk menjadi urusan rumah tangganya inilah disebut desentralisasi. ${ }^{34}$

Philipus M Hadjon ${ }^{35}$ mengemukakan, desentralisasi mengandung makna bahwa wewenang untuk mengatur dan mengurus urusan pemerintahan tidak semata-mata dilakukan oleh Pemerintah Pusat, melainkan juga dilakukan oleh satuan-satuan pemerintahan yang lebih rendah baik dalam bentuk satuan territorial maupun fungsional. Satuan-satuan pemerintahan yang lebih rendah diserahi dan dibiarkan mengatur dan mengurus sendiri sebagian urusan pemerintahan.

Ismail Husin, ${ }^{36}$ mengemukakan; Mengikuti sejarah pertumbuhan dan perkembangan organisasi-organisasi modern di beberapa negara, dapat diketahui bahwa desentralisasi pada hakikatnya merupakan suatu konsep yang lahir setelah sentralisasi mencapai wujudnya. Ini berarti bahwa desentralisasi tak mungkin lahir tanpa didahului sentralisasi, sebab sebelum desentralisai dilaksanakan sentralisasi yang mula-mula diperlukan.

34 Titik Triwulan Tutik, Konstruksi Hukum Tata Negara Indonesia Pasca Amandemen UUD 1945, Cetakan Ketiga, (Jakarta; Prenadamedia Group, 2015) hlm 250.

35 Philipus M Hadjon, et al, Pengantar Hukum Administrasi Indonesia, (Yogyakarta; Gajah Mada Universty, 1993) hlm 111.

${ }^{36}$ Ismail Husin, disampaikan pada saat Pidato Wisuda Rapat Senat Terbuka Institut Pemerintahan Dalam Negeri, pada tanggal 16 Juli 1996, dikutip dari, TitikTriwulan Tutik, Op Cit, hlm 251 
Menurut Joeniarto, ${ }^{37}$ desentralisasi adalah memberikan wewenang dari pemerintah negara kepada pemerintah lokal untuk mengatur dan mengurus urusan tertentu sebagai urusan rumah tangganya sendiri.

Joeniarto mengemukakan tiga elemen pokok dalam desentralisasi. ${ }^{38}$ Pertama, pembentukan organisasi pemerintahan otonom. Kedua, pembagian wilayah negara menjadi daerah otonom. Ketiga, penyerahan wewenang untuk mengatur dan mengurus urusan pemerintahan kepada daerah otonom. Dalam negara kesatuan kedua aktivitas tersebut dilakukan oleh pemerintah melalui proses hukum. Dengan kata lain, bahwa dalam desentralisasi adalah wewenang Pemerintah Pusat.

Adapun penyerahan wewenang kepada daerah dalam Undang-undang Pemerintahan Daerah yang pernah berlaku dapat dilakukan melalui dua cara;

1) Penyerahan penuh, artinya baik tentang asas-asasnya (prinsip-prinsipnya) maupun tentang cara menjalankan kewajibannya (pekerjaan) yang diserahkan itu, diserahkan semuanya kepada daerah (hak otonom)

2) Penyerahan tidak penuh, artinya penyerahan hanya mengenai caranya menjalankan saja, sedangkan asas-asasnya (prinsip-prinsipnya) ditetapkan oleh Pemerintah Pusat sendiri. ${ }^{39}$

Aneka bentuk desentralisasi pada dasarnya dapat dibedakan menurut tingkat peralihan kewenangan. Kewenangan untuk merencanakan, memutuskan, dan mengatur dari Pemerintahan Pusat ke lembaga-lembaga yang lain. Ada empat bentuk utama desentralisasi, yaitu (1) dekonsentrasi, (2) delegasi kelembaga-lembaga semi-otonom atau antar daerah (parastatal), (3) pelimpahan kewenangan (devolusi), ke Pemerintah Daerah, dan (4) peralihan fungsi dari lembaga-lembaga negara ke lembaga swadaya masyarakat (LSM). ${ }^{40}$

Pertama, dekonsentrasi mencakup redistribusi tanggung jawab administratif hanya di dalam badan Pemerintah Pusat. Menurut Henry Maddick, ${ }^{41}$ dekonsentrasi merupakan "the delegation of authority adequate for the discharge of specified function to staff of a central department who are situated outside the headquaters" (pendelegasian kewenangan sebagai fungsi-fungsi khusus dari Pemerintah Pusat terhadap staf yang ada di bawahnya). Parson

\footnotetext{
37 Joeniarto, Perkembangan Pemerintahan Lokal, (Jakarta; Bina Aksara, 1992) hlm 15.

38 Ibid, hlm 13.

39 Titik Triwulan Tutik, Op Cit, hlm 253

40 Dennis A Ronndinelli dan G Shabbir Cheema, Implemenring Decentralization Policies; An Introduction, dalam G Sahbbir Cheema dan Dennis A Rondinelli (editor), hlm 18, dikutip dari, Ni'matul Huda, Problematika... hlm 30.

41 Henry Maddick, Loc.Cit, dikutip dari Ibid, hlm 31
} 
mendefenisikan dekonsentrasi adalah ${ }^{42}$ "the sharing of power between members of the same rulling group having authority respectively in different areas of the state" (pembagian kekuasaan antara anggota-anggota dari kelompok yang sama di dalam suatu negara). Mawhood yang menyamakan dekonsentrasi dengan administrative decentralisation, mendefenisikan dekonsentrasi sebagai "transfer of administrative responsibility from central to local goverments." 43 (perpindahan tanggungjawab administratif dari Pemerintah Pusat

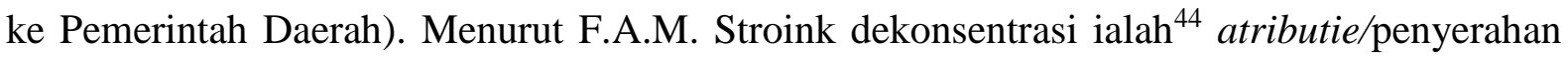
kewenangan menurut hukum publik kepada pejabat-pejabat departemen.

Kedua, delegasi kewenangan untuk mengambil keputusan dan manajemen atas fungsi-fungsi khusus kepada lembaga-lembaga yang tidak berada di bawah kontrol langsung kementrian Pemerintah Pusat. Seringkali lembaga-lembaga yang menerima delegasi peranperan pembangunan tersebut memiliki kewenangan semi otonom untuk melaksanakan tanggung jawabnya dan bahkan tidak berada di dalam struktur pemerintahan tetap. ${ }^{45}$

Ketiga, bentuk desentralisasi yang lain adalah berupaya menciptakan atau memperkokoh tingkat atau satuan-satuan pemerintah independen melalui devolusi peran dan kewenangan. Melalui devolusi, Pemerintah Pusat melepaskan fungsi-fungsi tertentu atau membentuk satuan-satuan baru pemerintah yang berada di luar kontrol langsungnya.

Keempat, di banyak negara desentralisasi dilakukan melalui peralihan tugas perencanaan dan tanggung jawab administratif tertentu, atau peralihan fungsi publik, dari pemerintah ke lembaga-lembaga sukarela, swasta atau non pemerintah (LSM). Pada kasus tertentu, pemerintah dapat memindahkan hak untuk memberi ijin, mengatur, atau mengawasi anggota-anggotanya dalam melaksanakan tugas-tugasnya yang sebelumnya dikontrol oleh pemerintah ke lembaga-lembaga paralel seperti asosiasi industri dan perdagangan nasional, lembaga profesional atau pakar partai politik, atau koperasi. ${ }^{46}$

Di kalangan ahli hukum Indonesia, desentralisasi didefinisikan secara beragam. Menurut RDH Koesoemahatmadja, ${ }^{47}$ secara harfiah kata desentralisasi berasal dari dua

42 Dikutip oleh Syarif Hidayat dan Bheunyamin Hoessein, "Desentralisasi...", Loc.Cit. dikutip dari Ibid...

43 Ibid

44 F.A.M. Stroink, Pemahaman Tentang Dekonsentrasi, diterjemahkan oleh Ateng Syafrudin, (Bandung; Refika Aditama, 2006) hlm 7. Dikutip dari, Ibid..

45 Dennis A. Rondinelli dan G. Shabbir Cheema, “ Implementing..., Op.Cit, hlm 18, dikutip dari, Ibid...

46 Ibid...

47 RDH Koesoemahatmadja, Pengantar Ke arah Sistem Pemerintahan Daerah Di Indonesia, Binacipta, Bandung, 1979. Dikutip kembali oleh Laica Marzuki dalam Berjalan-jalan di Ranah Hukum, Buku Kesatu, Edisi Revisi Cetakan Kedua, (Jakarta; Sekretariat Jenderal \& Kepanitiaan Mahkamah Konstitusi RI, 2006) hlm.160. Dikutip dari, Ibid, hlm 33. 
penggalan kata bahasa latin yakni: de berarti lepas, centrum berarti pusat. Makna harfiah dari desentralisasi adalah melepaskan diri dari pusat. Dalam makna ketatanegaraan, desentralisasi adalah penyerahan kekuasaan pemerintahan dari pusat kepada daerah-daerah. Desentralisasi merupakan staatkundige decentralisatie (desentralisasi ketatanegaraan), atau lebih sering disebut dengan desentralisasi politik, bukan ambtelijke decentralisatie, seperti halnya dengan dekonsentrasi. Dekonsentrasi merupakan ambtelijke decentralisatie, disebut pula delegatie van bevoegheid, yakni pelimpahan kewenangan dari alat perlengkapan negara pusat kepada instansi bawahan untuk melaksanakan pekerjaan tertentu dalam penyelenggaraan pemerintahan. Pemerintah Pusat tidak kehilangan kewenangannya, instansi bawahan melaksanakan tugas atas nama Pemerintah Pusat. Suatu delegatie van bevoegheid bersifat instruktif, rakyat tidak dilibatkan. Lebih tepat hubungan dekonsentrasi dinamakan mandaat van bevoegheid. Dalam pada itu, menurut R. Tresna, ${ }^{48}$ suatu pelimpahan kewenangan (delegation of authority) dalam staatskundige decentralisatie berakibat beralihnya kewenangan Pemerintah Pusat secara tetap. Pemerintah Pusat kehilangan kewenangan yang dilimpahkan, beralih kepada Pemerintah Daerah.

Amrah Muslimin ${ }^{49}$ mengartikan desentralisasi adalah pelimpahan wewenang pada badan-badan dan golongan-golongan dalam masyarakat dalam daerah tertentu untuk mengurus rumah tangganya sendiri.

Lebih jauh Amrah Muslimin ${ }^{50}$ membedakan desentralisasi menjadi tiga macam, yaitu: desentralisasi politik, desentralisasi fungsional, dan desentralisasi kebudayaan. Desentralisasi politik adalah pelimpahan kewenangan dari Pemerintah Pusat, yang menimbulkan hak mengurus kepentingan rumah tangga sendiri bagi badan-badan politik di daerah-daerah, yang dipilih oleh rakyat dalam daerah-daerah tertentu.

Desentralisasi fungsional adalah pemberian hak dan kewenangan pada golongangolongan untuk mengurus kepentingan dalam masyarakat, baik terikat maupun tidak pada suatu daerah tertentu, seperti mengurus kepentingan irigasi bagi golongan tani dalam suatu atau beberapa daerah tertentu (waterschap; subak Bali).

48 RDH Koesoemaatmadja, Pengantar Ke arah Sistem Pemerintahan Daerah Di Indonesia, Binacipta, Bandung, 1979. Dikutip kembali oleh Laica Marzuki dalam Berjalan-jalan di Ranah Hukum, Buku Kesatu, Edisi Revisi Cetakan kedua, Sekretariat Jenderal \& Kepanitiaan Mahkamah Konstitusi RI, Jakarta, 2006, hlm.160. Dikutip dari, Ibid, hlm 33.

49 Amrah Muslimin, Aspek-aspek Hukum Otonomi Daerah, (Bandung; Alumni, 1986) hlm 5.

50 Amrah Muslimin, Op.Cit., hlm 4. 
Desentralisasi kebudayaan (culturele decentralisatie) memberikan hak kepada golongan-golongan kecil dalam masyarakat (minoritas) menyelenggarakan kebudayaannya sendiri (mengatur pendidikan, agama, dan lain-lain.) ${ }^{51}$

Dianutnya desentralisasi dalam organisasi negara tidak berarti ditinggalkannya asas sentralisasi, karena kedua asas tersebut tidak bersifat dikotomis, melainkan kontinum. Pada prinsipnya, tidaklah mungkin diselenggarakan desentralisasi tanpa sentralisasi. Sebab desentralisasi tanpa sentralisasi, akan menghadirkan desintegrasi. Oleh karena itu Otonomi Daerah yang pada hakekatnya mengandung kebebasan dan keleluasaan berprakarsa, memerlukan bimbingan dan pengawasan pemerintah, sehingga tidak menjelma menjadi kedaulatan. Otonomi Daerah dan daerah otonom adalah ciptaan pemerintah. Walaupun demikian, hubungan antara daerah otonom dan pemerintah adalah hubungan antar organisasi dan bersifat resiprokal. ${ }^{52}$

Dalam negara kesatuan, penyelenggaraan desentralisasi dilakukan oleh Pemerintah Pusat. Penyelenggaraan disini mengandung arti penetapan strategi, kebijakan dan program, termasuk pembentukan peraturan perundang-undangan dan daerah otonom beserta penyerahan wewenangnya serta pengembangannya.

Otonomi Daerah merupakan esensi pemerintahan desentralisasi. Istilah otonomi berasal dari penggalan dua kata bahasa Yunani, yakni autos yang berarti berdiri sendiri dan nomos yang berarti undang-undang. Otonomi bermakna membuat undang-undang sendiri (zelfwetgeving) namun dalam perkembangannya konsepsi Otonomi Daerah selain mengandung arti zelfwetgeving (membuat perda-perda) juga utamanya mencakup zelfbestuur (pemerintahan sendiri). C.w Van Der Pot memahami konsep Otonomi Daerah sebagai eigen huishouding (menjalankan rumah tangganya sendiri). ${ }^{53}$

Otonomi Daerah adalah hak wewenang dan kewajiban daerah otonom untuk mengatur dan mengurus sendiri urusan pemerintahan dan kepentingan masyarakat setempat sesuai dengan peraturan perundang-undangan. ${ }^{54}$

Dalam konsep Otonomi Daerah dikenal beberapa sistem untuk menetapkan bidangbidang mana yang menjadi urusan Pemerintah Pusat dan mana yang merupakan kewenangan Pemerintah Daerah.

51 Ibid.

52 Bheunyamin Hoessein, "Hubungan...", Op. Cit, hlm. 199, dikutip dari, Ni'matul Huda, Problematika... Op Cit, hlm 36.

53 M.Laica Marzuki, dikutip dari, Ni'matul Huda, Hukum Pemerintahan Daerah, (Bandung; Nusamedia, 2009) hlm. 83

54 Pasal 1 angka 5 Undang-undang No. 32 Tahun 2004 tentang Pemerintahan Daerah 
Sistem itu antara lain $:^{.55}$

1. Sistem residu, menurut sistem ini telah ditentukan lebih dahulu tugas-tugas yang menjadi kewenangan Pemerintah Pusat, sedangkan sisanya menjadi urusan rumah tangga daerah;

2. Sistem material, berdasarkan sistem ini tugas daerah ditetapkan satu persatu secara limitatif atau terperinci;

3. Sistem formal, dalam sistem ini urusan yang termasuk urusan rumah tangga daerah tidak secara apriori ditetapkan dalam undang-undang;

4. Sistem otonomi riil, dalam sistem ini penyerahan tugas dan kewenangan kepada daerah didasarkan pada faktor yang nyata atau riil;

Undang-undang No. 22 Tahun 1999 tentang Pemerintahan Daerah memberikan perubahan mendasar dalam desain kebijakan hubungan antara Pemerintah Pusat dan Pemerintah Daerah. Desentralisasi kewenangan kepada pemerintah kabupaten dan kota dilakukan pada taraf yang signifikan. Pemerintah memberikan peluang yang sangat besar kepada daerah untuk mengatur daerahnya sesuai dengan potensi dan aspirasi yang berkembang di daerah tersebut, sepanjang tidak menyangkut urusan yang masih menjadi kewenangan Pemerintah Pusat. Sebagai pedoman ataupun aturan main ditingkat daerah, Pemerintah Daerah yang memiliki kesanggupan untuk melaksanakan Otonomi Daerah diperkenankan mengatur urusan daerahnya dalama bentuk Peraturan Daerah (Perda). ${ }^{56}$

Peraturan Daerah sebagai salah satu produk hukum yang berlaku di Republik Indonesia (RI) memiliki tempat dalam struktur hierarki Perundang-undangan Republik Indonesia sebagaimana diatur dalam TAP MPR No. III/MPR/2000 kemudian diganti dengan Undang-undang No.10 Tahun 2004 tentang Pembentukan Peraturan Perundang-undangan dan terakhir diganti lagi dengan Undang-undang No. 12 Tahun 2011 tentang Pembentukan Peraturan Perundang-Undangan. Dalam Pasal 7 undang-undang tersebut ditegaskan jenis dan hierarki peraturan perundang-undangan di Indonesia, yaitu ;

a. Undang-Undang Dasar Negara Republik Indonesia Tahun 1945;

b. Ketetapan MPR;

c. Undang-Undang/Peraturan Pemerintah Pengganti Undang-Undang;

d. Peraturan Pemerintah;

e. Peraturan Presiden;

f. Peraturan Daerah Provinsi;

g. Peraturan Daerah Kabupaten/Kota;

55 Loc Cit..

${ }^{56}$ Ni'matul Huda, Problematika...Op.Cit, hlm. 86. 
Menurut Bagir Manan ${ }^{57}$ peraturan perundang-undangan tingkat daerah adalah peraturan perundang-undangan yang dibuat oleh Pemerintah Daerah atau salah satu unsur Pemerintah Daerah yang berwenang membuat peraturan perundang-undangan tingkat daerah.

Mengenai pengertian Perda syari'ah atau penulis dalam penelitian ini menyebut dengan Perda berbasis syari'ah, satu istilah yang sulit dilacak dalam literatur hukum dan perundang-undangan. Istilah yang mencuat bersamaan dengan issu dan gerakan pemberlakuan Syari'at Islam tersebut biasanya digunakan untuk menyebut Rancangan Peraturan Daerah (Raperda) atau Peraturan Daerah (Perda) yang paling tidak dari sisi penamaan atau judulnya 'berbau syari'at' misalnya Perda tentang Zakat, Perda tentang Larangan Pelacuran dan lain sebagainya. Istilah Perda Syari'ah atau Perda berbasis syari'ah juga menjadi popular ketika terjadi penyusunan atau pembahasan sebuah Peraturan Daerah yang bersinggunggan atau mendapat perhatian lebih dari komunitas muslim. ${ }^{58}$ Secara umum dapat dikatakan bahwa Perda syari'ah atau Perda berbasis syari'ah sering dimaknai sebagai Perda yang diambil dari ketentuan-ketentuan legal Syari'at Islam baik yang bersifat tekstual maupun substansi ajarannya. ${ }^{59}$

Perda berbasis syari'ah setidaknya dapat diklasifikasikan dalam tiga hal, yaitu; (1) ketertiban masyarakat seperti pelarangan aktivitas pelacuran dan pembatasan distribusi konsumsi minuman beralkohol; (2) kewajiban dan keterampilan keagamaan seperti pembayaran zakat dan kemampuan baca tulis Al Qur'an; dan (3) simbolisme keagamaan berupa pakaian busana muslim. ${ }^{60}$

Penulis dalam penelitian ini mengartikan Perda berbasis syari'ah adalah Peraturan Daerah yang dibuat oleh Pemerintah Daerah (eksekutif dan legislatif) mengenai aspek-aspek tertentu berkaitan dengan Syari'at Islam.

\section{Syari’at Islam}

Dalam perkembangan perjalanan sejarah Islam, dapat ditemui berbagai ungkapan dan pandangan seputar hukum Islam. Bahkan seringkali dalam beberapa hal terdapat kerancuan dalam pengungkapan term yang dimaksudkan dengan hukum Islam. Paling tidak ada 3 term

57 Bagir Manan, Sistem dan Teknik...Op.Cit, hlm.4.

58 M. Darmizal, Keadilan untuk Aceh, Pemikiran Religious untuk Pemberdayaan Masyarakat Pasca Perdamaian RI-GAM dan Bencana Tsunami, Cetakan Pertama, (Bandung; IRIS Press, 2006) hlm 125, dikutip dari, Muntoha, Op.Cit, hlm 57

59 Rumadi, Perda Syari'at Islam; Jalan Lain menuju Negara Islam ? dalam Taswirul Afkar, Op. Cit, hlm 4 dikutip dari, Muntoha, Ibid, hlm 37

60 Arskal Salim, Perda Berbasis Agama dan Perlindungan Konstitusional Penegakan HAM, Jurnal Perempuan No. 60, Cetakan Pertama, (Jakarta; Yayasan Jurnal Perempuan, 2008) hlm 111. 
yang seringkali disebutkan mengenai hukum Islam yaitu, syari'ah, fiqih, dan hukum Islam itu sendiri. Untuk menghindari kesalah pahaman lebih lanjut dalam pembahasan ini, maka perlu dijelaskan terlebih dahulu pengertian ketiganya baik dari segi etimologi maupun terminologinya.

\section{a. Syari'ah (Syari'at)}

Sebagai hukum Tuhan, syari'ah menempati posisi paling penting dalam masyarakat Islam. Sebagian umat Islam meyakini syari'ah mencakup seluruh aspek kehidupan manusia, baik secara individual maupun kolektif. Kecenderungan mendefinisikan syari'ah secara luas semacam ini, sekalipun bermasalah, ${ }^{61}$ tetap muncul di dunia Islam hingga kini. ${ }^{62}$

Syari'ah (syari'at) berasal dari bahasa arab syara'a, "yang ditetapkan atau didekritkan", yang secara etimologi berarti "jalan tempat keluarnya air untuk minum" atau "tempat lalu air di sungai" atau "jalan ke mata air". Di dalam Al Qur'an, kata syari'ah muncul satu kali ${ }^{63}$ dengan pengertian jalan yang mesti diikuti. Kata bentukan syir'ah juga digunakan dengan pengertian jalan. ${ }^{64}$ Sementara akar kata syara'a muncul dua kali di dalam Al Qur'an, dengan Tuhan sebagai subyeknya ${ }^{65}$ dan dalam kaitannya dengan orang-orang yang membangkang kepada agama Tuhan. ${ }^{66} 67$

Secara istilah (terminologi), Hasbi Ash-Shiddiqy mengutip pendapat M.Syaltut yang mendefinisikan syari'ah sebagai hukum-hukum dan tata aturan yang Allah SWT syari'atkan bagi hambanya untuk diikuti. ${ }^{68}$ Menurut Faruq Nabhan, ${ }^{69}$ secara istilah, syari'ah berarti "segala sesuatu yang disyari'atkan Allah SWT kepada hamba-hamba-Nya". Sedangkan menurut Manna' al-Qathan, ${ }^{70}$ syari'ah berarti "segala ketentuan Allah SWT yang disyari'atkan bagi hamba-hamba-Nya, baik menyangkut akidah, ibadah, akhlak maupun muamalah".

61 Seperti ditunjukkan Abdallahi Ahmed al-Na'im, "Shari'a and Positive Legislation: Is an Islamic State Possible or Viable?", Kluwer Law International, 2000, hlm 29.

${ }^{62}$ Taufiq Adnan Amal dan Samsu Rijal Panggabean, Politik Syariat Islam: Dari Indonesia hingga Nigeria, (Jakarta; Pustaka Alvabet, 2004) hlm 2.

63 QS Al Jatsiyah (45) ayat 18

64 QS Al Maidah (5) ayat 48.

65 QS Asy Syura (42) ayat; 13

66 QS Al 'A'raf (7) ayat; 63

67 Ibid

68 Muhammad Hasbi Ash-Shiddiqy, Falsafah Hukum Islam, (Jakarta; Bulan Bintang,1993) hlm 31.

69 Muhammad Faruq Nabhan, Al-Madkhal li al-Tasyri' all Islami, Dar al-Shadir, t.th Jilid VIII, Beirut, hlm 10.

70 Manna' al-Qathan, al-Tasyri' wa al-Fiqh fi al-Islam, Muassasah al-Risalah, t.th., hlm 14 
Pendapat lain menyatakan (asy-syara'), asy-syari'at (sy-syari'ah) adalah apa yang digariskan/ditentukan oleh Allah dalam agama untuk pengaturan hidup hamba-Nya. Berdasarkan hal ini 'Abdullah Yusuf 'Ali menerjemahkan syari'at sebagai "the right of way of religion" (jalan agama yang betul) yang lebih luas dari sekedar ibadah-ibadah formal dan ayat-ayat hukum yang diwahyukan kepada Nabi Muhammad. ${ }^{71}$ Ia tidak lain dari ad-din (agama) itu sendiri, karena diantara pengertian ad-din adalah kekuasaan (al mulk), power (as sulthan) yang mengikat banyak orang. ${ }^{72}$ Nabi Yusuf yang sengaja menangkap saudaranya, seperti dikisahkan oleh Al Qur'an, sebenarnya tidak ingin memperlakukan ad-din al mulk (aturan/hukum Raja) kecuali atas kehendak Allah. ${ }^{73}$

Sebagai ad diin, Syari'at Islam sebenarnya mencakup segi keyakinan dan segi amalan dalam agama, tetapi menurut pemahaman fuqaha, istilah ini digunakan secara khusus untuk menunjukan ketentuan-ketentuan hukum yang berhubungan dengan perbuatan manusia (al ahkam al 'amaliyyah) atau ketentuan-ketentuan hukum membebani yang menyangkut perbuatan manusia (al ahkam at taklifiyyah al 'amaliyyah) ${ }^{74}$ Secara ringkas syari'at adalah ketentuan-ketentuan hukum sah (al ahkam asy syar'iyyah) yang dicapai melalui salah satu metode yang sah berupa dali-dalil tentang ketentuan hukum Allah yang disingkapkan kepada kita meneurut ketentuan keyakinan kita, baik yang bersifat qathi' (definitife) maupun yag bersifat zhanni (mengandung probabilitas), melalui nash atau istinbath (formulasi melalui metode tertentu). ${ }^{75}$

Dengan demikian, syari'at adalah hukum illahi, dengan pengertian bahwa ia adalah perwujudan kongkrit dari kemauan illahi melalui kepatuhan manusia untuk mengikuti tuntutan-Nya dalam kehidupan pribadi dan masyarakat. ${ }^{76}$ Perwujudan kemauan illahi itu bukan hanya satu perangkat ajaran-ajaran yang kongrit. Orang tidak hanya diminta agar menjadi dermawan, rendah hati, atau adil, tetapi juga diminta untuk melakukannya dalam keadaan khusus kehidupan yang disertai dengan sanksi dalam hal pelanggaran. ${ }^{77}$

71 Abdullah Yusuf Ali, The Holy Qur'an Tex, Translation and Comentary. Breenwood, Marlyland; Amana Corporation, 1409 H/1989 M, hlm 1297, dikutip dari, Rifyal Ka’bah, Hukum Islam Di Indonesia, (Jakarta; Universitas Yarsi, 1999) hlm 36.

72 Majma' al-Lughah al- 'Arabiyah Li Jamhuriyyah Mishr al 'Arabiyyah. Al Mu'jam al Wasith I ( Cairo; Daar al Ma'rif, 1400/1980) hlm 307, dikutip dari ibid...

73 QS Yusuf (13) ayat; 76.

74 Yusuf Hamid al 'Alim, al Maqashid al 'Ammah li asy Syari'ah al Islamiyyah (Riyadh; Ad Dir al Ilmiyyah li al Kitab al Islami, 1415/1997) hlm 19, dikutip dari, Rifyal Ka’bah, Loc.Cit, hlm 36.

75 Ibid, hlm 37.

76 Seyyed Hosein Nasr, Ideal and Realities of Islam, London; George Allen \& Unwin, 1979, hlm 93 dikutip dari, Ibid...

77 Rifyal Ka'bah. Ibid... 
Dalam pandangan kebanyakan kaum muslim, syari'ah biasanya diklasifikasikan ke dalam ibadah dan muamalah; ibadah mengatur hubungan manusia dengan Allah SWT, sedangkan mu'amalah mengatur hubungan antara manusia dengan manusia dan benda serta penguasa. Dengan demikian, menurut batasan yang disebutkan di atas, syari'ah mengontrol serta mengatur seluruh perilaku publik dan privat manusia. Ia memiliki aturan tentang kebersihan pribadi, perilaku seksual, dan membesarkan anak. Ia mengemukakan aturanaturan spesifik tentang shalat, puasa, sedekah, dan berbagai masalah agama lainnya. Ketentuan tentang masalah keperdataan dan kepidanaan juga tercakup dalam syari'ah. Disamping itu, syari'ah mengatur bagaimana individu berperilaku di dalam masyarakat bagaimana suatu kelompok berinteraksi dengan kelompok lain, bagaimana mengatasi masalah perbatasan, perselisihan konflik, dan peperangan antar negara, masalah kelompok minoritas (zimmi) di dalam negara bahkan dapat digunakan sebagai sarana untuk memecahkan masalah sipil dan kriminal internasional.

Berbeda dengan beberapa pendapat di atas yang memberikan definisi umum dan menyeluruh tentang syari'ah, Muhammad Said Al-Asymawi ${ }^{78}$ mendefinisikan syari'ah adalah ruh yang melaksanakan kandungan kaidah, penerapan, dan tafsir, bukan kaidah, penerapan atau tafsir atas syari'ah itu sendiri. Syari'ah adalah ruh pembaharuan dalam menciptakan kaidah baru, pemberlakuan terhadap permasalahan baru dan tafsir kekinian.

Pendapat Al-Asymawi yang berbeda ini didasarkan pandangan bahwa kecenderungan syari'ah dipahami juga sebagai hukum perundang-undangan sehingga harus diberlakukan disuatu negara. Padahal menurut Al-Asymawi, syari'ah tidak mengandung makna hukum perundang-undangan (taqnin) atau tasyri'iyyah melainkan al-thariq, al-manhaj, al-sabil yang berarti cara, metode, jalan, dan makna-makna serupa. ${ }^{79}$ Hal ini dikarenakan, sebagaimana lebih lanjut dijelaskan Al-Asymawi, mula-mula pengertian syari'ah merujuk pada makna aslinya, yakni manhajullah, sabilullah, thariqullah, dan seterusnya. Kemudian meluas hingga mencakup makna "kaidah-kaidah perundang-undangan (tasyri'iyyah) yang ada dalam Al Qur'an”. Meluas lagi sampai pada "kaidah-kaidah perundang-undangan yang tertera dalam hadist-hadist Nabi”. Lalu mengalami pergeseran hingga mencakup pengertian-pengertian

78 Muhammad Said Al-Asymawi, Ushul Al-Syari'ah, Cetakan Keempat (Kairo; Maktabah Madbuli Al-Shagir, 1996) hlm 178-179.

79 Muhammad Said Al-Asymawi, al-Islam al-Siyasi, (Kairo; 'Arabiyah li al-Tibaah wa al-Nasyr, 1987) hlm 186. 
"syuruh (komentar-komentar), tafsir, ijtihad, pendapat, fatwa, dan segenap hukum hasil-hasil penyimpulan dan penerapan kaidah-kaidah tersebut, yakni fiqih. ${ }^{80}$

Pendapat-pendapat di atas, dapat disederhanakan bahwa pengertian syari'ah secara bahasa telah disepakati akan tetapi secara terminologi terjadi perbedaan dalam pendefinisian secara umum, khusus, dan cara pandang.

\section{b. Fiqh, (Fiqih)}

Fiqih secara bahasa berarti "paham yang mendalam" 81 atau "mengetahui sesuatu dan memahaminya dengan baik" ${ }^{\prime 2}$. Secara istilah, fiqih menurut Abu Zahrah dalam kitab ushul fiqihnya, adalah mengetahui hukum-hukum syara' yang bersifat 'amaliyah yang dikaji dari dalil-dalilnya secara terperinci. Menurut al-Amidi, fiqih berarti "ilmu tentang seperangkat hukum syara' yang bersifat furuiyah yang didapatkan melalui penalaran dan istidlal. ${ }^{83}$ Dari definisi tersebut dapat diambil pengertian bahwa fiqih itu bukanlah hukum syara' itu sendiri, tetapi interpretasi terhadap hukum syara. Karena fiqih hanya merupakan interpretasi yang bersifat zanni yang terikat dengan situasi dan kondisi yang melingkupinya, maka fiqih senantiasa berubah seiring dengan perubahan waktu dan tempat. Secara mudahnya fiqih dapat diartikan sebagai dugaan kuat yang dicapai oleh seorang mujtahid dalam usahanya menemukan hukum Tuhan. ${ }^{84}$

\section{c. Hubungan Syari'ah (Syari'at) dengan Fiqh (Fiqih)}

Untuk membedakan antara syari'ah dengan fiqh, kita perlu mengetahui hubungan keduanya. Syari'ah sebagai hukum Allah SWT diturunkan di muka bumi dengan tujuan menegakkan kemaslahatan, kedamaian, dan kebahagiaan umat manusia. Syari'ah ada yang diterangkan secara eksplisit (tertulis jelas) dalam Al Qur'an dan ada pula yang bersifat implisit.

Hukum Allah SWT yang dituangkan dalam Al Qur'an secara eksplisit itu pun masih terbagi dalam dua bagian, yaitu: muhkam (terang) dan mutasyabih (samar) yang ditemui umat Islam pada masa Nabi Muhammad SAW telah dijelaskan melalui sunnah-sunnahnya dengan sempurna baik dalam bentuk ucapan, perbuatan, ketetapan, dan sifat yang beliau tampilkan.

80 Ibid

81 Muhammad Abu Zahrah, Ushul Fiqh, (Kairo; Darul Fikri al-Arabi, t.th) hlm 6.

82 Abu al-Hasan Ahmad Faris bin Zakariya, Mu'jam Maqayis al-Lughah, Jilid II (Mesir; Musthafa al-Babi alHalabi, 1970) hlm 442.

83 Lihat Fathurrahman Djamil, Filsafat Hukum Islam, (Jakarta; Logos Wacana Ilmu, 1997) hlm 8.

${ }^{84}$ Amir Syarifuddin, Pengertian dan Sumber Hukum Islam dalam Falsafah Hukum Islam, (Jakarta; Bumi Aksara dan Departemen Agama, 1992) hlm 15. 
Umat Islam harus tunduk pada ketentuan-ketentuan Al Qur'an dan As Sunnah tersebut. Namun demikian, penjelasan- penjelasan Rasul kala itu terikat oleh dimensi-dimensi kultural, situasi, kondisi, waktu, dan tempat sehingga penjelasan Rasul SAW tersebut mesti dilanjutkan melalui pengkajian-pengkajian dan penelitian-penelitian ijtihadi. Produk-produk pemikiran ijtihadi itulah yang disebut fiqih. ${ }^{85}$

Fiqih senantiasa berubah. Karena sifatnya yang berubah-ubah itu, fiqih biasa dinisbahkan kepada mujtahid yang memformulasikannya, seperti Fiqih Hanafi. Fiqih Syafi'i, Fiqih Syi'ah, dan sebagainya. Sedangkan syari'ah senantiasa dinisbahkan kepada Allah SWT dan Rasul-Nya. ${ }^{86}$

Secara ringkas fiqih adalah penjelasan terhadap syari'ah yang terang dan agak terang serta pemahaman dan penggalian terhadap kandungan syari'ah yang tidak tampak (samar).

\section{d. Hukum Islam}

Kata hukum Islam tidak ditemukan sama sekali di dalam Al Qur'an dan literatur hukum dalam Islam. Yang ada dalam Al Qur'an adalah kata syari'ah, fiqih, hukum Allah SWT, dan yang seakar dengannya. Kata-kata hukum Islam merupakan terjemahan dari term Islamic law dari literatur Barat. ${ }^{87}$

Untuk mengetahui lebih jelas tentang arti hukum Islam, perlu diketahui lebih dahulu arti dari kata "hukum". Sebenarnya tidak ada arti yang sempurna tentang hukum. Namun, untuk mendekatkan kepada pengertian yang mudah dipahami meski masih mengandung kelemahan, definisi yang diambil oleh Muhammad Muslehuddin dari Oxford English Dictionary perlu diungkapkan. Menurutnya hukum adalah the body of rules, wether proceeding, from formal enactment or from custom, which a parlicular state or community recopyizes as binding on its members or subjects. ${ }^{88}$ (Sekumpulan aturan, baik yang berasal dari aturan formal maupun adat yang diakui oleh masyarakat dan bangsa tertentu sebagai mengikat bagi anggotanya).

Bila hukum dihubungkan dengan Islam, maka hukum Islam berarti: "seperangkat peraturan berdasarkan wahyu Allah SWT dan sunnah Rasul tentang tingkah laku manusia

85 Fathurraham Djamil, Op. Cit, hlm 9-10

86 Ibid

87 Lihat Joseph Schaft, An Introduction to Islamic Law, (Oxport; University Press, 1964) hlm 1.

88 Muhammad Muslihuddin, Philosophy of Islamic Law and The Orientalists, (Lahore; Islamic Publications L.td, 1980) hlm 17. 
mukallaf yang diakui dan diyakini berlaku dan mengikat untuk semua umat yang beragama Islam. ${ }^{89}$

Dari definisi yang dikemukakan di atas dapat dipahami bahwa hukum Islam mencakup hukum syari'ah dan hukum fiqih, karena arti syari'ah dan fiqih terkandung didalamnya.

\section{Hubungan Syari'at dengan Negara.}

Wacana Syari'at Islam bersifat pelik jika dihubungkan dengan perannya terhadap negara. Dalam literatur sejarah Islam, dapat ditemui ketidak kesepakatan para pemikir Islam tentang konsep hubungan agama (syari'at) dengan negara. Masalah hubungan politik antara lslam dan negara seringkali muncul dari pandangan-pandangan tertentu yang dirumuskan dengan cara sedemikian rupa sehingga Islam disejajarkan secara konfrontatif dengan negara, seolah-olah antara keduanya tidak mungkin dibangun hubungan yang saling melengkapi.

Setidaknya pada awal kandungan ideologis dan kerangka konstitusional menjadi faktor-faktor yang sangat penting dalam menentukan watak sebuah negara lslam. Jika memang demikian yang terjadi, maka sebuah tinjauan umum mengenai teoritisasi politik Islam akan berguna sebagai landasan untuk pemahaman yang baik mengenai inti masalah ini.

Agama sebagaimana dinyatakan banyak kalangan, dapat dipandang sebagai instrumen ilahiah untuk memahami dunia. ${ }^{90}$ Islam, dibandingkan dengan agama-agama lain, sebenarnya merupakan agama yang paling mudah untuk menerima premis semacam ini. Alasan utamanya terletak pada ciri Islam yang paling menonjol, yaitu sifatnya yang "hadir dimanamana" (omnipresence). Ini sebuah pandangan yang mengakui bahwa "dimana-mana", kehadiran Islam selalu memberikan "panduan moral yang benar bagi tindakan manusia". 91

Pandangan ini telah mendorong sejumlah pemeluknya untuk percaya bahwa Islam mencakup cara hidup yang total. Penjabarannya dinyatakan dalam syari'ah (hukum Islam). Bahkan sebagian kalangan muslim melangkah lebih jauh dari itu: mereka menekankan bahwa "Islam adalah sebuah totalitas yang padu yang menawarkan pemecahan terhadap semua masalah kehidupan.

Pandangan holistik terhadap Islam tersebut mempunyai beberapa implikasi. Salah satunya, pandangan itu telah mendorong lahirnya sebuah kecenderungan untuk memahami

\footnotetext{
89 Amir Syarifuddin, Op.Cit, hlm 14.

90 Bahtiar Effendy, Islam dan Negara; Transformasi Pemikiran dan Praktik Politik Islam di Indonesia, (Jakarta; Paramadina, 1998) hlm 6.

91 Fazrul Rahman, Op Cit, hlm. 4.
} 
Islam dalam pengertiannya yang "literal" yang hanya menekankan dimensi "luar" (exterior) dan mengabaikan dimensi "kontekstual" dan "dalam" (interior). Dalam soal sifat holistik Islam ini, Qamaruddin Khan menulis sebagaimana dikutip Bahtiar Effendi: ${ }^{92}$

"Ada pandangan yang salah dalam pikiran sejumlah kaum Muslim dewasa ini bahwa Al Qur'an berisi penjelasan yang menyeluruh tentang segala sesuatu. Kesalahpahaman ini disebabkan oleh pandangan yang keliru terhadap ayat Al Qur'an yang berbunyi demikan : "Dan Kami turunkan kepadamu Kitab Suci untuk menjelaskan segala sesuatu dan petunjuk serta rahmat dan kabar gembira bagi orang-orang yang berserah diri ${ }^{, 93}$

Ayat ini dimaksudkan untuk mengatakan bahwa Al Qur'an mengandung penjelasan tentang segala aspek panduan moral dan bukan penjelasan terhadap segala obyek kehidupan. Al Qur'an itu tidak berisikan segala sesuatu yang berhubungan dengan pengetahuan umum.”

Mengakui syari'ah sebagai suatu sistem kehidupan yang menyeluruh merupakan suatu hal, sementara memahaminya secara benar adalah hal lain lagi. Bahkan, dalam konteks "bagaimana syari'ah harus dipahami” inilah, sebagaimana dilihat oleh Fazrul Rahman, terletak persoalan yang sebenarnya. Ada sejumlah faktor yang mempengaruhi dan membentuk hasil pemahaman kaum muslim terhadap syari'ah. Situasi ideologis, kultural, dan intelektual, atau apa yang disebut Arkoun sebagai "estetika penerimaan" (aesthetics of reception), sangat berpengaruh dalam menentukan bentuk dan isi pemahaman. Karenanya kendatipun setiap muslim menerima prinsip-prinsip umum yang tertuang dalam syari'at, pemahaman mereka tentang ajaran Islam diwarnai perbedaan-perbedaan.

Munculnya berbagai madzhab fiqih, teologi, dan filsafat Islam, misalnya menunjukkan bahwa ajaran-ajaran Islam itu multi-interpretatif. Karena itu, sebagaimana telah dikatakan oleh banyak pihak, Islam tidak bisa dan tidak seharusnya dilihat secara monolitik.

Politik Islam tidak bisa dilepaskan dari sejarah Islam yang multi interpretatif semacam ini. Pada sisi lain, hampir setiap muslim percaya akan pentingnya prinsipprinsip Islam dalam kehidupan politik, pada saat yang sama, karena sifat Islam yang multi interpretatif itu, tidak pernah ada pandangan tunggal mengenai bagaimana seharusnya Islam dan politik dikaitkan secara pas. Bahkan, sejauh yang dapat ditangkap dari perjalanan diskursus intelektual dan historis pemikiran dan praktik politik Islam, ada banyak pendapat yang berbeda dan bahkan bertentangan mengenai hubungan yang sesuai antara Islam dan politik.

92 Bahtiar Effendy, Op.Cit, hlm. 9.

93 QS An Nahl (16) ayat; 89 
Tentang hubungan agama dan negara dalam Islam, menurut Munawir Sjadzali, ${ }^{94}$ ada tiga aliran yang menanggapinya. Pertama, aliran yang menganggap bahwa Islam adalah agama yang paripurna, yang mencakup segala-galanya, termasuk masalah negara. Oleh karena itu agama tak dapat dipisahkan dari negara dan urusan negara adalah urusan agama serta sebaliknya. ${ }^{95}$ Aliran kedua, mengatakan bahwa Islam tidak ada hubungannya dengan negara karena Islam tidak mengatur kehidupan bernegara atau pemerintahan. Menurut aliran ini, Nabi Muhammad tidak punya misi untuk mendirikan negara. ${ }^{96}$ Aliran ketiga, berpendapat bahwa Islam tidak mencakup segala-galanya, tapi mencakup seperangkat prinsip dan tata nilai etika tentang kehidupan bermasyarakat termasuk bernegara. Oleh karena itu, dalam bernegara, umat Islam harus mengembangkan dan melaksanakan secara garis besar oleh Islam. ${ }^{97}$

Dalam model hubungan agama dan negara. Hussein Muhammad ${ }^{98}$ menyebutkan dua model, yaitu hubungan integralistik dan hubungan simbiosis mutualistik.

Hubungan integralistik dapat diartikan sebagai hubungan totalitas, dimana agama dan negara merupakan suatu kesatuan yang tidak dapat dipisahkan. Keduanya merupakan dua lembaga yang menyatu (integral). Ini juga memberikan pengertian bahwa negara merupakan suatu lembaga politik dan sekaligus lembaga agama.

M. Amien Rais mengatakan dalam makalahnya, bahwa Islam adalah din dan daulah (agama dan negara). ${ }^{99}$ Pernyataan itu juga merupakan pendapat hampir semua penulis modern. Muhammad Yusuf Musa dalam bukunya Nizham al-Hukmi fii al-Islam, telah berkali-kali menegaskan bahwa Islam adalah din dan daulah. ${ }^{100}$

Model hubungan kedua adalah hubungan simbiosis-mutualistik. Model hubungan ini, menegaskan bahwa antara agama dan negara terdapat hubungan yang saling membutuhkan. Menurut pandangan ini, agama harus dijalankan dengan baik. Hal ini hanya dapat terlaksana bila ada lembaga yang bernama negara. Sementara itu negara juga tidak dapat dibiarkan

94 Munawir Sjadzali, Islam dan Tata Negara, (Jakarta; LP3ES, 1985) hlm 235-236.

95 Diantara mereka yang termasuk ke dalam kategori pendukung alur pemikiran semacam ini adalah Rasyid Ridha, Sayyid Quthb, dan Abul al-A'la al-Maududi.

96 Tokoh pemikir yang kontroversial ini adalah Ali Abdul al-Raziq.

97 Para pendukung pemikiran ini, diantaranya, Husayn Haykal, Fazrul Rahman, dan Qamaruddin Khan.

98 Hussein Muhammad, Islam dan Negara Kebanggaan; Tinjauan Politik, dalam Ahmad Suaedy, Pergulatan Pesantren dan Demokrasi, (Yogyakarta; LKIS) hlm 92-94.

99 M. Amien Rais, "Negara dan Masyarakat dalam System Religio Politik Islam”. Makalah disampaikan dalam diskusi Konsep Negara dalam Islam di Fakultas Hukum UII pada 4 Oktober 1987, t.d, hlm 7.

100 Muhamad Yusuf Musa, an-Nizham al-Hukmi fi al-Islam, Al-Qahira: Daral-Ma'rifa, 1964, hlm 7. 
berjalan sendiri tanpa agama. Sebab tanpa agama akan terjadi kekacauan dan amoral dalam negara.

\section{Prinsip-prinsip Pembentukan Peraturan Perundang-undangan}

Dalam studi ilmu dan teori perundang-undangan, paling tidak ada 4 syarat bagi peraturan perundang-undangan yang baik yaitu: yuridis, sosiologis, filosofis, dan sesuai dengan teknik perancangan peraturan perundang-undangan yang baik. ${ }^{101}$ Teknik perancangan peraturan perundang-undangan yang baik harus memenuhi ketepatan struktur, ketepatan pertimbangan, ketepatan dasar hukum, ketepatan bahasa (peristilahan), dan ketepatan dalam pemakaian huruf dan tanda baca. ${ }^{102}$ Selain keempat syarat tersebut di atas, pembuatan peraturan perundang-undangan yang baik juga harus memperhatikan asas-asas formal dan asas material sebagaimana dikemukakan Van der Vlies. ${ }^{103}$

Syarat tersebut adalah sebagai berikut :

1) Asas-asas formal meliputi ; (a) Asas tujuan yang jelas (b) Asas organ/lembaga yang tepat (c) Asas perlunya peraturan (d) Asas dapat dilaksanakan (e) Asas konsensus.

2) Asas-asas material meliputi; (a) Asas tentang terminologi dan sistematika yang benar (b) Asas tentang dapat dikenali (c) Asas perlakuan yang sama dalam hukum (d) Asas kepastian hukum (e) Asas pelaksanaan hukum sesuai keadaan individual.

\section{Perda Dalam Hierarki Perundang-undangan Negara Republik Indonesia.}

Peraturan Daerah (Perda) sebagai salah satu produk hukum yang berlaku di Republik Indonesia (RI) memiliki tempat dalam struktur hierarki Perundang-undangan Republik Indonesia sebagaimana diatur dalam TAP MPR No. III/MPR/2000 kemudian diganti dengan Undang-undang No. 10 Tahun 2004 tentang Pembentukan Peraturan Perundangundangan dan sekarang diganti lagi dengan Undang-undang No. 12 Tahun 2011 tentang Pembentukan Peraturan Perundang-undangan. Dalam Pasal 7 Undang-undang tersebut ditegaskan jenis dan hierarkhi peraturan perundang-undangan di Indonesia yaitu;
a. Undang-undang Dasar Negara Republik Indonesia Tahun 1945;
b. Ketetapan MPR;
c. Undang-undang/Peraturan Pemerintah Pengganti Undang-undang;
d. Peraturan Pemerintah;

\footnotetext{
101 Bagir Manan, Dasar-dasar Perundang-Undangan Indonesia, (Jakarta; Ind-Hill.co, 1992) hlm 13.

102 Ibid., hlm 17.

103 Ibid., hlm 19.
} 
e. Peraturan Presiden;

f. Peraturan Daerah Provinsi;

g. Peraturan Kabupaten / Kota;

Secara hierarki, Perda merupakan jenis peraturan perundang-undangan paling bawah yang disebutkan dalam Undang-undang No. 12 tahun 2011 tersebut, kendati dalam rumusan Pasal 7 ayat (3) undang-undang tersebut disebutkan bahwa jenis peraturan perundangundangan selain yang disebutkan di atas diakui keberadaannya dan mengikat secara hukum sepanjang diperintahkan oleh peraturan perundang-undangan yang lebih tinggi. Dengan diberlakukannya undang-undang ini, maka terdapat beberapa jenis peraturan perundangundangan di Indonesia yang tidak termasuk dalam hierarkhi perundang-undangan, seperti : Keputusan Presiden, Peraturan Menteri, Keputusan Menteri dan beberapa jenis peraturan lainnya.

Implikasi yuridis dari tidak dimuatnya beberapa jenis peraturan diatas dalam Undangundang No. 12 Tahun 2011 tentang Pembentukan Peraturan Perundang-undangan adalah terjadinya ketidakjelasan kedudukan beberapa peraturan tersebut dalam hierarki peraturan perundang RI. Jika Perda merupakan jenis peraturan paling bawah yang disebutkan oleh Undang-undang No. 12 Tahun 2011 tentang Pembentukan Peraturan Perundang-undangan, maka bagaimana kedudukan Perda dengan Keputusan Presiden misalnya. ${ }^{104}$

\section{Kewenangan Pemerintah Daerah dalam membuat Peraturan Daerah.}

Menurut Bagir Manan, peraturan perundang-undangan tingkat daerah diartikan sebagai "peraturan perundang-undangan yang dibentuk oleh Pemerintah Daerah atau salah satu unsur Pemerintah Daerah yang berwenang membuat peraturan perundang-undangan tingkat daerah". ${ }^{105}$

Pemerintah Daerah, baik provinsi, maupun kabupaten/kota memiliki kewenangan untuk membuat Peraturan Daerah (Perda). Dalam Pasal Undang-undang No. 32 Tahun 2004 tentang Pemerintahan Daerah dijelaskan bahwa yang dimaksud dengan Perda adalah peraturan yang dimiliki oleh pemerintah provinsi dan/atau pemerintah kabupaten/kota. ${ }^{106}$

\footnotetext{
104 Rifqi Nizami Karsayuda, "Tinjauan Terhadap Peraturan Daerah (Perda) Syariah di Kalimantan Selatan" (Makalah dalam blog rifqi.wordpress.com, diakses tanggal 20 April 2008).

105 Bagir Manan, op.cit.

106 Lihat Lembaran Negara Republik Indonesia Tahun 2004 No. 125 dan Tambahan Lembaran Negara Republik Indonesia No. 4437.
} 
Secara terperinci Bab VI Undang-undang No. 32 Tahun 2004 tentang Pemerintahan Daerah menjelaskan tentang prosedur pembentukan Perda, materi muatan Perda asas yang harus terkandung dalam Perda termasuk sanksi yang dapat dimuat dalam Perda tersebut.

Pertama: Prosedur pembentukan Perda. Perda dibentuk/ditetapkan oleh Kepala Daerah setempat bersama dengan DPRD. Artinya Perda yang dibuat di tingkat provinsi ditetapkan oleh Gubernur setempat bersama dengan DPRD provinsi, demikian pula di tingkat kabupaten/kota. Usul pembentukan Perda dapat dilakukan oleh Kepala Daerah sebagai Kepala Eksekutif Daerah dan oleh DPRD sebagai Legislatif Daerah. Hal ini berlaku terhadap seluruh usulan Perda kecuali rancangan Perda mengenai APBD yang harus berasal dari Kepala Daerah (eksekutif) saja. Dalam pembentukan Perda masukan dari masyarakat harus diberi ruang, baik dalam proses awal pembentukannya, maupun pada saat perumusan terhadap materi Perda tersebut.

Kedua : Materi muatan Perda disesuaikan dengan kewenangan yang dimiliki daerah sesuai dengan asas desentralisasi dan tugas pembantuan. Perda berisikan penjabaran lebih lanjut dari peraturan perundang-undangan yang lebih tinggi dengan memperhatikan ciri khas daerah. Dalam konteks ini, materi Perda ditafsirkan dan berisi rumusan lebih lanjut dari peraturan perundang-undangan di atasnya. Selain itu, materi Perda juga dapat memuat hal-hal yang terkait dengan ciri khas daerah tersebut. Selain itu materi Perda juga harus memuat beberapa asas dalam pembentukan Perda yaitu; pengayoman; kemanusiaan; kebangsaan; kekeluargaan; kenusantaraan; Bhineka Tunggal Ika; keadilan; kesamaan kedudukan dalam hokum; dan pemerintahan; ketertiban dan kepastian hukum; dan/atau keseimbangan, keserasian, dan keselarasan. ${ }^{107}$

Ketiga : Sebagai salah satu produk peraturan perundang-undangan di Republik Indonesia yang berada pada hierarki bawah, Perda dapat memuat ketentuan sanksi pidana dan denda yang jenis sanksinya lebih ringan daripada sanksi yang dimuat dalam berbagai peraturan perundang-undangan yang lebih tinggi. Dalam ketentuan Pasal 143 ayat (1), (2), dan (3) Undang-undang No. 32 Tahun 2004 tentang Pemerintahan Daerah diatur mengenai sanksi yang dapat diatur dalam perda yaitu :

a. Perda dapat memuat ketentuan tentang pembebanan biaya paksaan penegakan hukum, seluruhnya atau sebagian kepada pelanggar sesuai dengan peraturan perundangan.

b. Perda dapat memuat ancaman pidana kurungan paling lama 6 (enam) bulan atau denda paling banyak Rp. 50.000.000,00 (lima puluh juta rupiah).

107 Ketentuan perihal asas materi Perda diatur dalam Pasal 138 Undang-undang No. 32 Tahun 2004 tentang Pemerintahan Daerah. 
c. Perda dapat memuat ancaman pidana atau denda selain sebagaimana dimaksud pada ayat (2), sesuai dengan yang diatur dalam peraturan perundangan lainnya.

Keempat : Sebagai produk hukum yang dikeluarkan oleh Pemerintah Daerah dalam menjalankan tugasnya berdasarkan asas desentralisasi dan tugas pembantuan. Prosedur pembentukan, maupun materi Perda dilakukan melalui verifikasi oleh Pemerintah Pusat sebagaimana ditegaskan dalam Pasal 145 Undang-undang No. 32 Tahun 2004 tentan Pemerintahan Daerah. Perda yang dianggap melanggar kepentingan umum dan/atau bertentangan dengan peraturan perundang-undangan yang lebih tinggi dapat dibatalkan oleh Pemerintah Pusat melalui Keputusan Presiden. Selambat-lambatnya setelah 7 (tujuh) hari sejak dibatalkan Kepala Daerah harus memberhentikan pelaksanaan Perda tersebut dan selanjutnya DPRD dan Kepala Daerah harus mencabut Perda tersebut.

Bagi Kepala Daerah dan DPRD yang merasa keberatan atas pembatalan Perda dari Pemerintah Pusat dapat mengajukan keberatan melalui Mahkamah Agung. Jika keberatan tersebut diterima, maka Perda tersebut diberlakukan kembali dengan terlebih dahulu dikeluarkan Keputusan Presiden yang membatalkan Keputusan Presiden sebelumnya yang menyatakan Perda tersebut tidak berlaku. Apabila Pemerintah Pusat tidak mengeluarkan Keputusan Presiden untuk membatalkan Perda tersebut, maka Perda tersebut dengan sendirinya dinyatakan berlaku.

Kelima : Setelah Perda dibuat dan dilaksanakan, masyarakat memiliki kesempatan untuk melakukan "kontrol" terhadap Perda tersebut dengan melakukan review terhadapnya. Ada dua mekanisme yang dapat digunakan publik untuk melakukan review terhadap Perda yaitu melalui Mahkamah Agung (judicial review) dan melalui Pemerintah Pusat (executive review). Review yang diajukan ke Mahkamah Agung menuntut keaktifan dari masyarakat dan terbatas hanya dalam waktu 180 (seratus delapan puluh hari) hari sejak Perda tersebut diundangkan. Sedangkan mekanisme review melalui Pemerintah Pusat c.q Departemen Dalam Negeri (Depdagri) dilaksanakan sebagai bentuk pengawasan Pemerintah Pusat terhadap produk hukum Pemerintah Daerah sebagamana dijelaskan di atas. Kendati demikian publik dapat pro aktif meminta Pemerintah Pusat untuk menggunakan kewenangannya ini guna mengawasi Perda-perda yang dianggap bermasalah.

\section{Penutup}

Pemberlakuan Perda berbasis syari'ah dapat dilihat dari persfektif peraturan perundang-undangan. Dalam rangka ini pula harus mengacu kepada teori pertingkatan hukum (hierarki norma hukum/stufenbau theory) dari Kelsen yang dimaksudkan untuk mengkaji 
aspek kepastian hukum dalam kaitannya dengan keberlakuan hukum secara yuridis, karena kepastian hukum ditentukan oleh validitas atau kesesuaian hukum dalam tatanan hierarki peraturan perundang-undangan. ${ }^{108}$ Selain itu juga dimaksudkan untuk menganalisis keterkaitan antar norma hukum yang mengacu pada nilai filosofis yang berintikan pada rasa keadilan dan kebenaran, maupun nilai-nilai sosiologis yang sesuai dengan tata nilai budaya yang berlaku di masyarakat.

Atas dasar itu, norma dasar akan menghasilkan sistem hukum yang konsisten sehngga terjadinya konflik antar norma akan tunduk pada norma-normanya sendiri. Misalnya prinsip lex posteriori derogate legi periori atau prinsip lex superior derogate legi inferiori apabila suatu norma yang lebih tinggi tingkatannya membatalkan suatu norma yang lebih rendah. Karakteristik dari norma yang bersumber pada norma dasar meliputi konsistensi dan prinsip legitimasi. Prinsip legitimasi menyatakan bahwa suatu norma tetap berlaku dalam suatu sistem hukum sampai daya lakunya diakhiri melalui suatu cara yang ditetapkan dalam sistem hukum, atau digantikan oleh norma lain yang diberlakukan oleh norma hukum tersebut. ${ }^{109}$ Dalam pelaksanaannya teori stufenbau dapat dianggap sebagai sistem hukum, karena terlihat dalam hukum positif bahwa susunan hukum merupakan tatanan mulai dari hukum dasar sampai pada peraturan-peraturan yang paling bawah tidak boleh bertentangan satu sama lain. ${ }^{110}$ Stufenbau menyatakan bahwa secara formal hukum merupakan susunan hierarki dari hubungan-hubungan normatif. Norma yang satu berhubungan dengan norma yang lain, norma yang pertama lebih tinggi tingkatannya daripada norma yang kedua dan demikian selanjutnya berjenjang dari atas ke bawah. Hal ini berarti, isi nilai dari suatu norma dari norma yang di bawah dan berikutnya tidak boleh bertentangan atau tidak boleh tidak bersesuaian dengan norma yang diatasnya. Setiap norma hukum memperoleh pengesahan dari norma hukum yang di atasnya dan pada tingkat terakhir semua norma hukum memperoleh pengesahan dari norma dasar. ${ }^{111}$

Suatu peraturan hukum tertentu harus dapat dikembalikan kepada peraturan hukum yang lebih tinggi tingkatannya. Dengan perkataan lain dapat dikatakan bahwa peraturanperaturan hukum positif disusun secara bertingkat ke bawah kesuatu yang melaksanakan

\footnotetext{
108 Hans Kelsen, dikutip dari, Muntoha, Op.Cit, hlm. 318.

${ }^{109}$ Ibid, hlm. 320.

${ }^{110}$ Kusnu Goesniadhi, Loc.Cit, hlm. 39 .

${ }^{111}$ Ibid, hlm. 40.
} 
norma-norma hukum tersebut secara konkrit. Konsekuensinya suatu peraturan hukum tertentu dapat dievaluasi kesesuainnya dengan peraturan hukum yang lebih tinggi tingkatannya. ${ }^{112}$

Dalam kaitannya dengan teori stufenbau ini, maka jika diperhatikan secara seksama Indonesia menganut teori tersebut yang dapat dirujuk dari Undang-undang No. 12 Tahun 2011 tentang Pembentukan Peraturan Perundang-undangan dan peraturan sebelumnya yaitu, TAP MPRS No. XX/MPRS/1966, tentang Momerandum DPRGR Mengenai Sumber Hukum dan Tata Urutan Peraturan Perundang-undangan, TAP MPR No. III/MPR/2000 tentang Sumber Hukum dan Tata Urutan Peraturan Perundang-undangan dan Undang-undang No.10 tahun 2004 tentang Pembentukan Peraturan Perundang-undangan. ${ }^{113}$ Kemudian undang-undang ini diganti dengan Undang-undang No. 12 tahun 2011 tentang Pembentukan Peraturan Perundang-undangan. Menurut Pasal (2) Undang-undang No. 12 tahun 2011 tentang Pembentukan Peraturan Perundang-undangan, Pancasila merupakan sumber dari segala sumber hukum negara (norma fundamental negara/staat fundamental norm) atau norma dasar (graundnorm, basicnorm) yang menempati urutan tertinggi dipuncak piramida hukum, kemudian diikuti oleh Undang-undang Dasar 1945, serta hukum dasar tidak tertulis atau konvensi ketatanegaraan sebagai aturan dasar negara (staatgraundgesetz), Ketetapan MPR kemudian undang-undang atau Peraturan Pemerintan Pengganti Undang-undang (formale gesetz), serta peraturan pelaksana dan peraturan otonom (verordegung and aotonome satzung) yang dimulai dari Peraturan Pemerintah, Peraturan Presiden dan Peraturan Daerah. $^{114}$

Secara konstitusional maupun peraturan perundang-undangan lainnya Perda Berbasis Syari'ah telah mendapatkan jaminan dari Pasal 29 UUD 1945 yang menyatakan;

(1) Negara berdasarkan atas Ketuhanan Yang Maha Esa

(2) Negara menjamin kemerdekaan tiap-tiap penduduk untuk memeluk agamanya masingmasing dan beribadat menurut agama dan kepercayaannya itu,

Pasal 18 ayat (6) UUD 1945 yang menyatakan:

Pemerintah Daerah berhak menetapkan Peraturan Daerah dan peraturan-peraturan lain untuk melaksanakan otonomi dan tugas pembantuan

Berdasarkan ketentuan peraturan perundang-undangan di atas, beberapa elemen masyarakat di berbagai daerah di Indonesia kemudian meresponnya dengan mengaspirasikan pemberlakuan Perda berbasis syari'ah melalui produk Perdanya masing-masing. Ketentuan

\footnotetext{
112 Ibid,

${ }^{113}$ Sirajuddin, Fatkhurohman dan Zulkarnain, Legislatif Drafting, dikutip dari, Muntoha, Loc.Cit...

${ }^{114}$ Ibid, hlm. 321.
} 
dari Pasal 18 UUD 1945 tersebut di atas selaras dengan kebijakan Otonomi Daerah yang pertama kalinya melalui Undang-undang No. 22 Tahun 1999 tentang Pemerintahan Daerah yang telah memberikan legitimasi terhadap lahirnya produk Perda-perda yang kemudian dipersepsikan sebagai Perda berbasis syari'ah. Bahkan ketika Undang-undang No. 22 Tahun 1999 tersebut diganti dengan Undang-undang No. 32 Tahun 2004 tentang Pemerintahan Daerah, masalah ini mendapat pengesahan kembali seperti yang termuat dalam Pasal (136) ayat (3) yang menyebutkan;

Peraturan Daerah merupakan penjabaran lebih lanjut dari peraturan perundang-undangan yang lebih tinggi dengan memperhatikan ciri khas masing-masing daerah.

Ayat (4) dari pasal tersebut menegaskan;

Peraturan Daerah dilarang bertentangan dengan kepentingan umun dan/atau dengan peraturan perundang-undangan yang lebih tinggi.

Demikian juga penegasan yang termuat dalam Pasal 14 Undang-undang No. 12 Tahun 2011 tentang Pembentukan Peraturan Perundang-undangan, yang menyatakan

Materi muatan Peraturan Daerah provinsi dan peraturan dareah kabupaten/kota berisi materi muatan dalam rangka penyelenggaraan otonomi daerah dan tugas pembantuan serta menampung kondisi khusus daerah dan/atau penjabaran lebih lanjut Peraturan Perundangundangan yang lebih tinggi.

Adapun mekanisme pembatalan Perda diatur dalam Pasal 145 Undang-undang No. 32 Tahun 2004 tentang Pemerintahan Daerah dapat dilakukan dengan cara sebagai berikut;

Perda yang dianggap melanggar kepentingan umum dan/atau bertentangan dengan peraturan perundang-undangan yang lebih tinggi dapat dibatalkan oleh Pemerintah Pusat melalui Keputusan Presiden. Selambat-lambatnya setelah 7 (tujuh) hari sejak dibatalkan, Kepala Daerah harus memberhentikan pelaksanaan Perda tersebut dan selanjutnya DPRD dan Kepala Daerah harus mencabut Perda tersebut.

Bagi Kepala Daerah dan DPRD yang merasa keberatan atas pembatalan Perda dari Pemerintah Pusat dapat mengajukan keberatan melalui Mahkamah Agung. Jika keberatan tersebut diterima, maka Perda tersebut diberlakukan kembali dengan terlebih dahulu dikeluarkan Keputusan Presiden yang membatalkan Keputusan Presiden sebelumnya yang menyatakan Perda tersebut tidak berlaku. Apabila Pemerintah Pusat tidak mengeluarkan Keputusan Presiden untuk membatalkan Perda tersebut, maka Perda tersebut dengan sendirinya dibatalkan. 


\section{Daftar Pustaka}

Abu al-Hasan Ahmad Faris bin Zakariya, Mu’jam Maqayis al-Lughah, Mesir, Musthafa al-Babi alHalabi, 1970.

Abu Zahrah, Muhammad, Ushul Fiqh, Darul Fikri al-Arabi, Kairo, t.th

Amal, Taufik Adnan dan Samsu Rijal Panggabean, Politik Syari'at Islam; Dari Indonesia Hingga Nigeria, Pustaka Alvabet, Jakarta, 2004.

Amrusy, Fahmi, Otonomi Daerah dalam Negara Kesatuan, dalam Abdurrahman (editor), Beberapa Pemikiran Tentang Otonomi Daerah, Media Sarana Press, Jakarta, 1987.

Al-Asymawi, Muhammad Said, al-Islam al-Siyasi, 'Arabiyah li al-Tibaah wa al-Nasyr, Kairo, 1987. Ushul Al-Syari’ah, Maktabah Madbuli al-Shagir, Kairo, 1996.

Al-Na'im, Abdullahi Ahmed, "Shari'a and Positive Legislation: Is an Islamic State Possible or Viable?”, Kluwer Law International, 2000.

Al-Qathan, Manna', al-Tasyri’ wa al-Fiqh fi al-Islam, Muassasah ar-Risalah, t.th.

Al-Syathibi, Al-Muwafaqat fi Ushul al-Ahkam, t.t., Dar al-Fikr, t.th.

Asshiddiqie, Jimly, Pengantar Hukum Tata Negara, jilid I, Cetakan Pertama, Konstitusi Press, Jakarta, 2006.

Azhary, Pengantar Hukum Tata Negara, jilid I, Cetakan Pertama, Konstitusi Press, Jakarta, 2006.

Azhari, Aidul Fitriciada, Sistem Pengambilan Keputusan Demokrasi Berdasarkan Konstitusi, Muhammadiyah Universty Press, Surakarta, 2000. 
Busroh, Abu Daud, Pergeseran Kekuasaan Eksekutif, Cetakan Keenam, Aksara Baru, Jakarta, 1986.

Departemen Agama RI, Al-Qur'an dan Terjemahnya, Jakarta, 1994.

Effendy, Bachtiar, Islam dan Negara; Transformasi Pemikiran dan Praktik Politik Islam di Indonesia, Paramadina, Jakarta, 1998.

Fajar, Mukti, Tipe Negara Hukum, Banyumedia, Malang, 2004.

Hadjon, M. Philipus, Pengkajian Ilmu Hukum Dogmatik (Normatif), Fakultas Hukum Universitas Airlangga, Surabaya, 1994.

Huda, Ni'matul, Hukum Tata Negara (Kajian Teoritis dan Yuridis Terhadap Konstitusi Indonesia), PSH FH UII, Yogyakarta, 1999.

Hukum Pemerintahan Daerah, Nusamedia, Bandung, 2009.

, Problematika Pembatalan Peraturan Daerah, FH UII Press, Yogyakarta, 2010.

Kansil, CST, Pengantar Ilmu Hukum dan Tata Hukum Indonesia, Balai Pustaka, Jakarta, 1989.

Ka'bah, Rifyal, Penegakan Syari’at Islam di Indonesia, Khairul Bayan, Jakarta, 2004.

Mahfud MD., Moh., Politik Hukum di Indonesia, LP3ES, Jakarta, 1998.

, Dasar dan Struktur Ketatanegaraan Indonesia, UII Press, Yogyakarta, 1993

Muhammad, Hussein, Islam dan Negara Kebangsaan: Tinjauan Politik, dalam Ahmad Suaedy, Pergulatan Pesantren dan Demokrasi, LKIS, Yogyakarta, 2000. 
Muntoha, Otonomi Daerah dan Perkembangan “Peraturan Daerah Bernuansa Syari'ah”, Safiria Insani Press, Yogyakarta, 2010.

Musa, Muhammad Yusuf, an-Nizham al-Hukmi fii al-Islam, Al-Qahira, Dar al-Ma’rifa, 1964.

Muslihuddin, Muhammad, Philosophy of Islamic Law and The Orientalists, Islamic Publications Ltd, Lahore, 1980.

Mu'allim, Amir dan Yusdani, Konfigurasi Pemikiran Hukum Islam, Cetakan Pertama, UII Press, Yogyakarta, 1999.

Prasetyo, Teguh, Hukum dan Sistem Hukum Berdasarkan Pancasila, Media Perkasa, Yogyakarta, 2013.

Rofiq, Ahmad, Pembaharuan Hukum Islam di Indonesia, Gama Media, Yogyakarta, 2001.

Rosjadi, Rahmat dan Rais Ahmad, Formalisasi Syari'at Islam dalam Persfektif Tata Hukum, Ghalia Indonesia, Bogor, 2006.

Rozali, Abdullah, Pelaksanaan Otonomi Luas dan Isu Federalisme sebagai Alternatif, Raja Grafindo Persada, Jakarta, 2000.

Salim, Arskal dan Azyumardi Azra, "Negara dan Syariat Dalam Perspektif Politik Hukum Indonesia”, dalam Burhanuddin (ed.), Syariat Islam Pandangan Muslim Liberal, Jakarta, 2003.

Sjadzali, Munawir, Islam dan Tata Negara, LP3ES, Jakarta, 1985.

Soimin, Pembentukan Peraturan Perundang-undangan Negara di Indonesia, UII Press, Yogyakarta, 2010.

Sirajuddin, Fatkuhurrohman dan Zulkarnaen, Legislative Drafting : Pelembagaan Metode Partisitif dalam Pembentukan Peraturan Perundang-undangan, Cetakan Pertama, Yappika, Jakarta, 2006. 
Syarif , Aminoeddin, Perundang-undangan Dasar, Jenis, dan Teknik Membuatnya, Rienekka Cipta, Jakarta, 1997.

Syarifuddin, Amir, Pengertian dan Sumber Hukum Islam dalam Falsafah Hukum Islam, Bumi Aksara dan DEPAG, Jakarta, 1992.

Sunny, Ismail, Pergeseran Kekuasaan Eksekutif, Cetakan Keenam, Aksara Baru Jakarta, 1986.

Thaib, Dahlan, Pancasila Yuridis Ketatanegaraan, UPP-AMPYKPN, Yogyakarta, 1991.

Tuti, Titik Triwulan, Konstruksi Hukum Tata Negara Indonesia Pasca Amandemen UUD 1945, Prenadamedia Group, Jakarta, 2015.

Utrecht, E., Pengantar Dalam Hukum Indonesia, Ichtiar, Jakarta, 1957.

Wahyono, Padmo, Indonesia Negara Berdasarkan atas Hukum, Cetakan Pertama, Ghalia, Indonesia, Jakarta, 1983.

Yamin, Muh. Naskah Persiapan UUD 1945, Prapanca, Jakarta, 1959.

Jurnal Hukum Vol. 1 Nomor 14, Januari, 2007.

Jurnal Perempuan Nomor 60 Tahun 2009.

Jurnal Konstitusi, Pusat Kajian Konstitusi Fak. Syariah IAIN Antasari kerjasama dengan MKRI, Vol. I Nomor 1, Nopember 2008.

Jurnal Konstitusi, Pusat Kajian Konstitusi Fak. Syariah IAIN Antasari kerjasama dengan MKRI, Vol. III Nomor 2, Nopember 2010.

Jurnal Konstitusi, Pusat Kajian Konstitusi Fak. Syariah IAIN Antasari kerjasama dengan MKRI, Vol. IV Nomor 1, Juni 2011. 
Jurnal Konstitusi, Pusat Kajian Konstitusi Fak. Syariah IAIN Antasari kerjasama dengan MKRI, Vol. II Nomor 1, September 2013. 
Jurnal Khazanah: Jurnal Studi Islam dan Humaniora Vol. 14. No. 1 Juni 2017
Perda Berbasis Syariah......27-41 Hayatun Na'imah 